\title{
DIGESTIBILIDADE DE NUTRIENTES E PARÂMETROS RUMINAIS E SANGÚINEOS DE NOVILHOS NELORE ALIMENTADOS COM FONTES PROTÉICAS E ENERGÉTICAS COM DIFERENTES DEGRADABILIDADES RUMINAIS
}

\author{
PAOLA RANZANI GABARRA
}

Dissertação apresentada à Escola Superior de Agricultura "Luiz de Queiroz", Universidade de São Paulo para obtenção do título de Mestre em Agronomia, Área de Concentração: Ciência Animal e Pastagens.

\section{PIRACICABA}

Estado de São Paulo - Brasil

Novembro - 2001 


\title{
DIGESTIBILIDADE DE NUTRIENTES E PARÂMETROS RUMINAIS E SANGÚINEOS DE NOVILHOS NELORE ALIMENTADOS COM FONTES PROTÉICAS E ENERGÉTICAS COM DIFERENTES DEGRADABILIDADES RUMINAIS
}

\author{
PAOLA RANZANI GABARRA
}

Zootecnista

Orientador: Prof. Dr.FLÁVIO AUGUSTO PORTELA SANTOS

Dissertação apresentada à Escola Superior de Agricultura "Luiz de Queiroz", Universidade de São Paulo para obtenção do título de Mestre em Agronomia, Área de Concentração: Ciência Animal e Pastagens.

\section{PIRACICABA}

Estado de São Paulo - Brasil

Novembro - 2001 
Dados Internacionais de Catalogação na Publicação (CIP) DIVISÃO DE BIBLIOTECA E DOCUMENTAÇÃO - ESALQ/USP

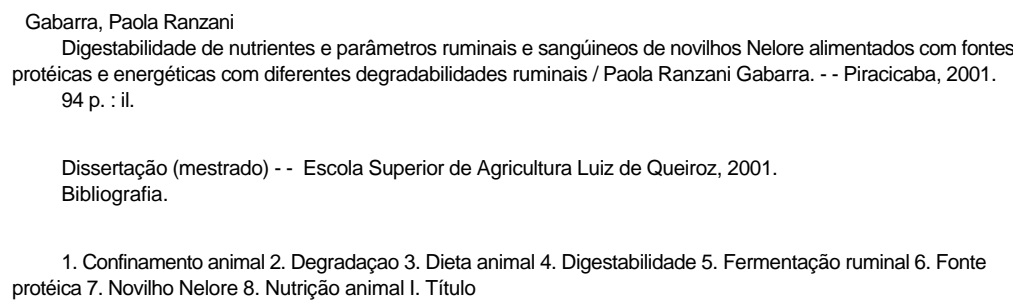

CDD 636.291

\section{"Permitida a cópia total ou parcial deste documento, desde que citada a fonte - $\mathrm{O}$ autor"}


Aos meus queridos pais,

ANTONIO CARLOS GABARRA

\section{E}

\section{LENICE GEMA RANZANI GABARRA \\ Que me apoiaram em todas \\ as etapas de minha vida}

Dedico. 


\section{AGRADECIMENTOS}

À Escola Superior de Agricultura Luiz de Queiroz (USP) e ao Departamento de Produção Animal, pela oportunidade de realização deste curso.

À Fundação de Amparo a Pesquisa do Estado de São Paulo (FAPESP), pelo auxílio à pesquisa durante 0 transcorrer do curso.

Ao Prof. Dr. Flávio Augusto Portela Santos, pela orientação segura, pelos ensinamentos valiosos, confiança e exemplo profissional.

Ao Prof. Dr. José Manuel Correa de Simas e Prof. Dr. Alexandre Vaz Pires, pelos ensinamentos, sugestões, colaboração na execução deste trabalho, e exemplo profissional.

Aos demais professores do Departamento de Produção Animal, pelos ensinamentos.

Aos meus pais, Lenice e Carlos, minhas irmãs Carla e Renata, meus cunhados Eduardo e Ovídio, e meus sobrinhos Letícia, Heloísa, Neto e João Victor pelo amor, confiança e grande estímulo para execução deste trabalho.

Ao Getulio, pelo amor, carinho, incentivo e ajuda ao longo deste trabalho.

As minhas grandes amigas, Gabriela, Tatiana B., Paula e Tatiana pela amizade, incentivo e agradável convivência durante todos os anos.

À minha avó Jovina e minha madrinha Syrtes por estarem sempre ao meu lado.

À Carla Maris Bittar Nussio pela amizade, pela grande ajuda e pela agradável convivência. 
Aos colegas Hugo Imaizumi e Márcia pela amizade e pela colaboração durante a execução deste trabalho.

Ao Juliano Fernandes, pela realização das cirurgias nos animais para implantação das cânulas.

Ao Laureano, pelo grande apoio durante a primeira fase deste trabalho.

Ao funcionário do Laboratório de Bromatologia e Nutrição Animal do Departamento de Produção Animal Carlos César Alves, pela colaboração nas análises químicas.

Às pessoas que, direta ou indiretamente, contribuíram para a realização deste trabalho. 


\section{SUMÁRIO}

Página

LISTA DE TABELAS................................................................................... viii

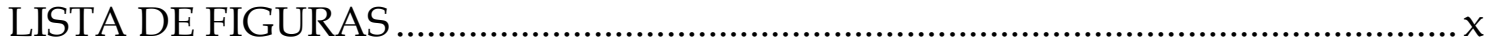

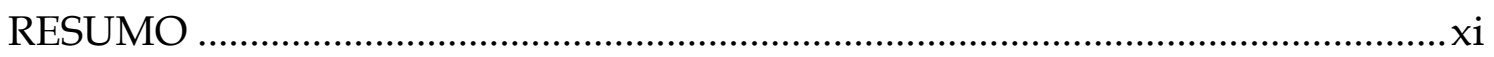

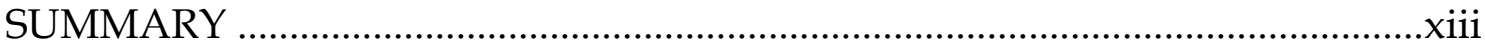

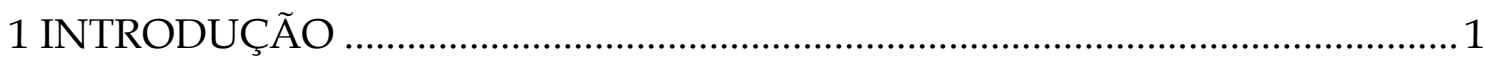

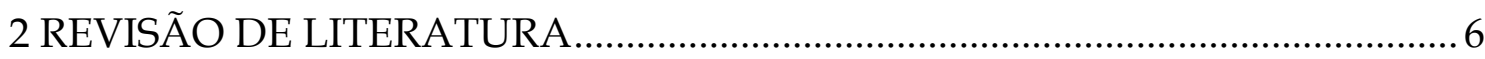

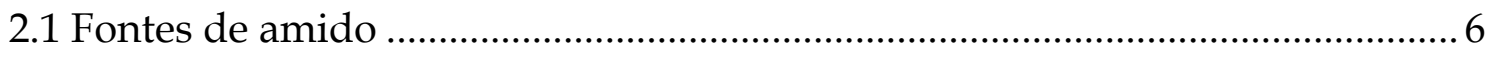

2.1.1 Caracterização da molécula de amido ....................................................... 6

2.1.2 Processamento dos grãos de cereais....................................................... 9

2.1.3 Digestão e metabolismo de amido pelos tecidos esplânicos ....................... 15

2.2 Proteína ........................................................................................................... 19

2.2.1 Síntese de proteína microbiana e fermentação ruminal .............................. 19

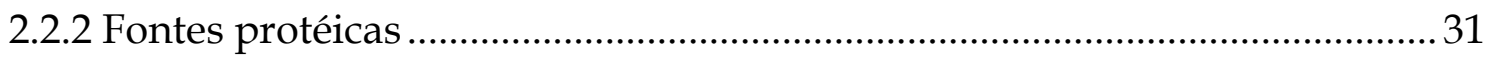

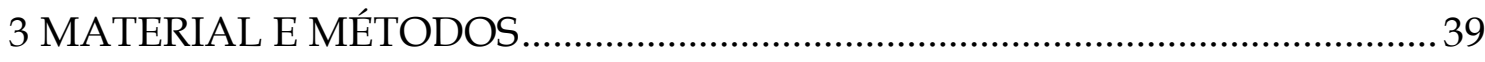

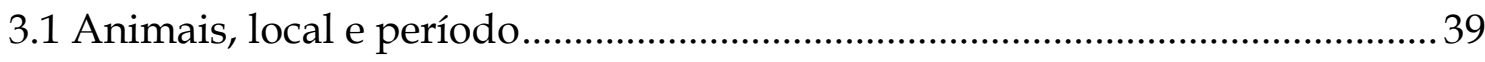

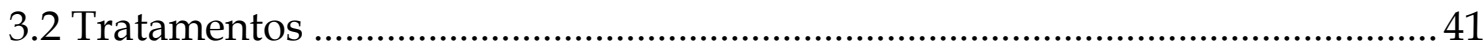

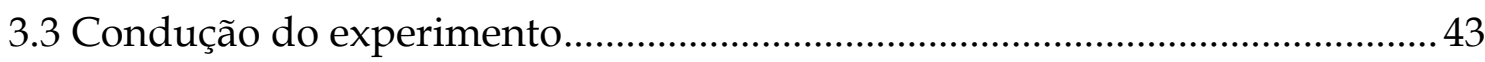

3.4 Processamento e análises das amostras ..................................................... 47 
3.4.1 Determinação de MS, MO, PB, amido, FDN e FDA....................................... 47

3.4.2 Análises do fluido ruminal .......................................................................... 47

3.4.3 Determinação da digestibilidade dos nutrientes.............................................. 48

3.4.4 Determinação de uréia plasmática .....................................................................49

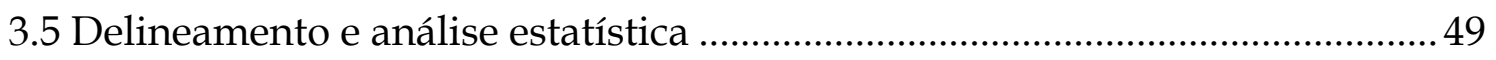

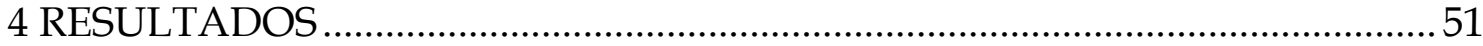

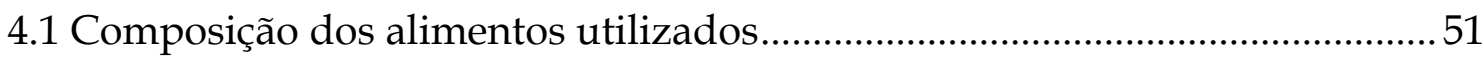

4.1.1 Milho floculado e milho moído........................................................................52

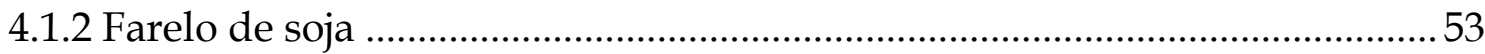

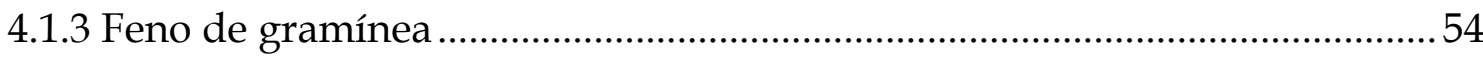

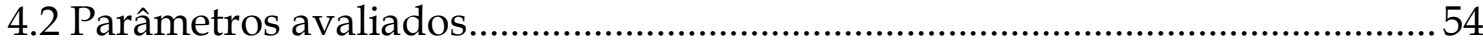

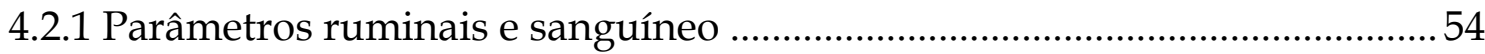

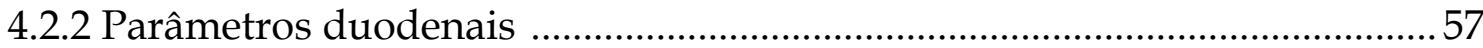

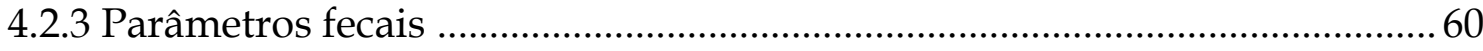

4.3 Consumo de matéria seca e digestibilidade dos nutrientes..............................62

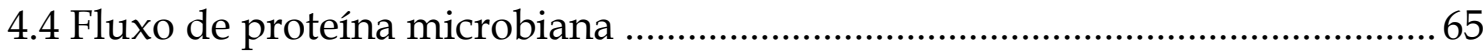

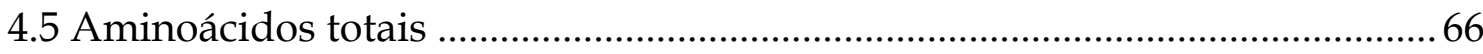

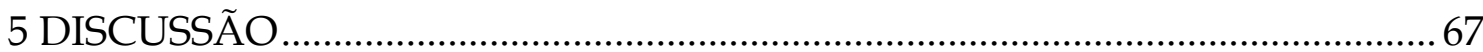

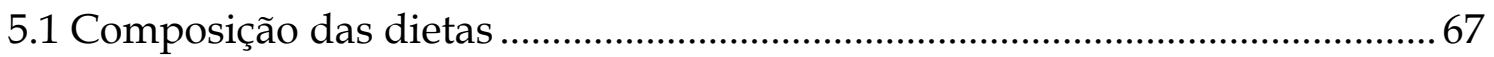

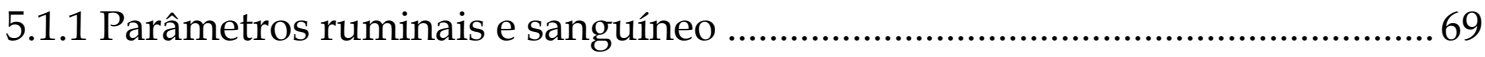

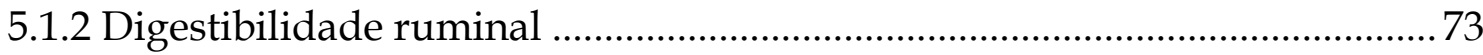

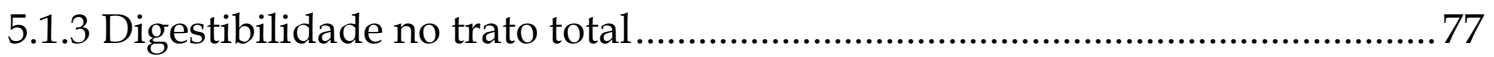

5.1.4 Fluxo de proteína microbiana e aminoácidos totais ............................................ 80

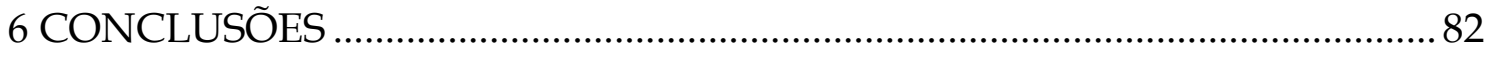

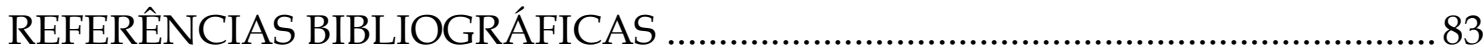




\section{LISTA DE TABELAS}

Página

1 Composição das dietas experimentais em \% da matéria seca ............................ 42

2 Tamanho de partículas do milho conforme o processamento............................43

3 Quadro esquemático de análise de variância..........................................................50

4 Composição das dietas em \% da MS ........................................................................ 51

5 Composição química dos alimentos ....................................................................52

6 Efeito dos tratamentos sobre os parâmetros avaliados no fluido ruminal e

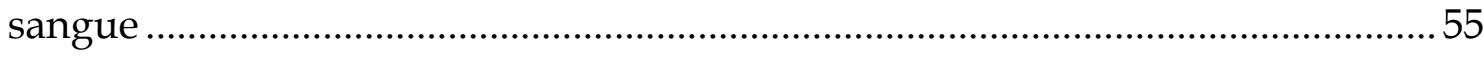

7 . Efeito dos tratamentos sobre a digestibilidade ruminal dos nutrientes ........58

8 Efeito dos tratamentos sobre as concentrações de nutrientes no bolo alimentar

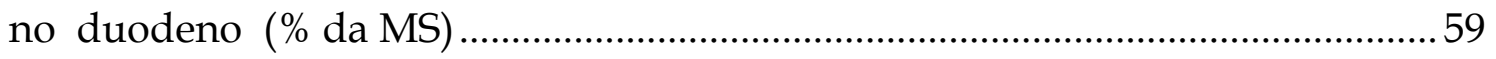

9 Efeito dos tratamentos sobre os parâmetros avaliados nas fezes em \% da

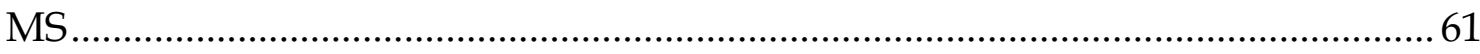

10 Efeitos dos tratamentos sobre o consumo e digestibilidade de MS.................62 
11 Efeitos dos tratamentos sobre a digestibilidade aparente dos nutrientes no trato total.

12 Digestibilidade ruminal das dietas em \% da MS ingerida...............................66 


\section{LISTA DE FIGURAS}

Página

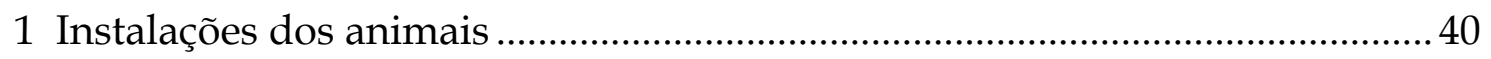

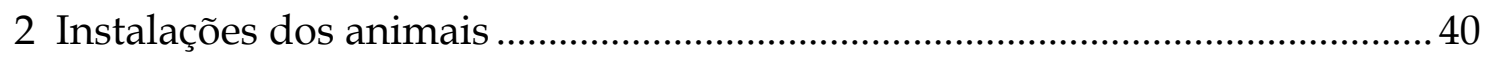

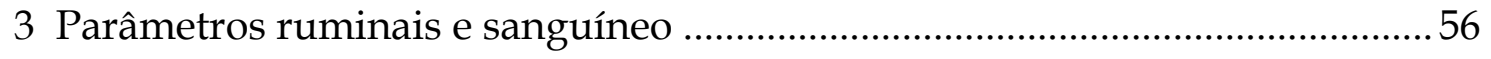

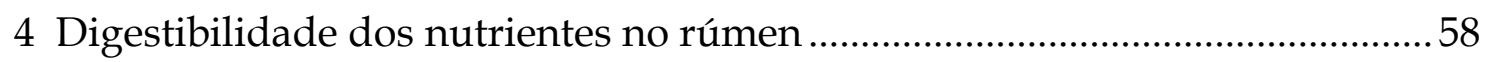

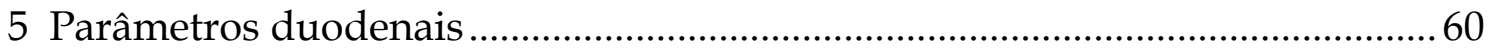

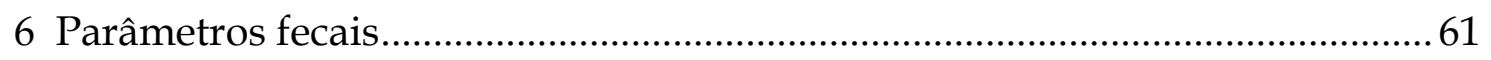

7 Digestibilidade dos nutrientes no trato total....................................................... 64 


\section{DIGESTIBILIDADE DE NUTRIENTES E PARÂMETROS RUMINAIS E SANGÚINEOS DE NOVILHOS NELORE ALIMENTADOS COM FONTES PROTÉICAS E ENERGÉTICAS COM DIFERENTES DEGRADABILIDADES RUMINAIS}

Autora: PAOLA RANZANI GABARRA Orientador: Prof. Dr.FLÁVIO AUGUSTO PORTELA SANTOS

\section{RESUMO}

Foram utilizados 4 novilhos Nelore, pesando ao redor de $300 \mathrm{Kg}$, canulados no rúmen e duodeno, em um delineamento em Quadrado Latino 4x4, com o objetivo de se testar a possibilidade de melhor sincronização da degradação ruminal de fontes energéticas e protéicas, através da utilização de 2 formas de processamento de milho (moagem fina $(1,5 \mathrm{~mm})$ x floculação $(300 \mathrm{~g} / \mathrm{l})$ e 2 fontes protéicas (farelo de soja x uréia). As dietas continham $13 \%$ de feno de gramínea tropical e $87 \%$ de concentrado, resultando em valores de PB ao redor de $13 \%$ e $83 \%$ de NDT. A floculação do milho resultou em menor concentração de amido no conteúdo duodenal, sugerindo uma maior 
degradação deste no rúmen, o que explica a redução de $\mathrm{N}-\mathrm{NH}_{3}(\mathrm{P}<0,01)$, de $\mathrm{pH}$ $(P<0,15)$ e o aumento de $C_{3}(P<0,01)$ no fluido ruminal. $A$ concentração de uréia plasmática também foi reduzida com a floculação do milho em comparação com a moagem fina. O provável aumento da degradação ruminal do amido através da floculação do milho, resultou em aumento significativo $(P<0,01)$ da digestibilidade deste nutriente no trato digestivo total, com um incremento ao redor de 10 unidades percentuais $(89,22 \times 98,90 \%)$ em comparação com a moagem fina. Entretanto, a digestibilidade da MS no trato digestivo total não foi aumentada $(P>0,05)$ com a floculação do milho, provavelmente devido à redução $(P<0,01)$ da digestibilidade do FDN. A substituição do farelo de soja por uréia não afetou $(P>0,05)$ a fermentação ruminal, nem o consumo e a digestão de nutrientes no trato digestivo total. 


\section{PROTEIN AND STARCH SOURCES VARYING IN RUMEN DEGRADABILITY ON NUTRIENT DIGESTIBILITIES, RUMINAL AND BLOOD PARAMETERS OF NELORE STEERS}

Author: PAOLA RANZANI GABARRA Adviser: Prof. Dr.FLÁVIO AUGUSTO PORTELA SANTOS

\section{SUMMARY}

Four Nelore steers, cannulated in the duodenum and in the rumen, averaging $300 \mathrm{~kg}$ of live weight, were used in a $4 \times 4$ Latin Square design, to test the improvement of ruminal synchronization of starch and protein degradation. Two methods of corn processing (fine grinding $(1,5 \mathrm{~mm})$ vs steam flaking $(300 \mathrm{~g} / \mathrm{l})$ ) and 2 protein sources (soybean meal vs urea) were compared in a $2 \times 2$ factorial arrangement. The diets contained $13 \%$ of tropical grass hay and $87 \%$ of concentrate, averaging 13\% CP and 83\% TDN. Steam flaking of corn decreased $(P<0,01)$ starch concentration in duodenal digesta, suggesting a higher ruminal degradation of this nutrient. This would explain the actual decrease in ruminal $\mathrm{N}-\mathrm{NH}_{3}(\mathrm{P}<0,01)$ and $\mathrm{pH}(\mathrm{P}<0,15)$ and the increase in molar 
concentration of ruminal $C_{3}(P<0,01)$. PUN concentration was decreased $(P<0,01)$ by steam flaking of corn compared to fine grinding. The probable increase of starch degraded in the rumen and post rumen, due to steam flaking, increased $(P<0,01)$ digestibility of this nutrient in the total tract $(89,22 x$ $98,90 \%)$, compared to fine grinding. However, the total tract DM digestibility was not increased $(P>0,05)$ by steam flaking, probably due to the decrease $(P<0,01)$ in NDF digestibility. The replacement of soybean meal by urea had no effect $(P>0,05)$ on ruminal fermentation and on intake and total tract digestion of nutrients. 


\section{INTRODUÇÃO}

Por muito tempo acreditou-se que seria vantajoso para ruminantes, se a degradação da proteína e do amido da dieta ocorressem preferencialmente no intestino delgado em comparação com a fermentação ruminal. Supunha-se que evitando as perdas no processo fermentativo, maiores quantidades de energia e proteína seriam economizadas, resultando em melhora no desempenho animal.

No tocante ao amido, trabalhos produzidos na última década, têm mostrado que o desempenho de novilhos de corte e de vacas leiteiras é superior quando as fontes deste nutriente são preferencialmente degradadas no rúmen, em detrimento da digestão intestinal. Isto tem sido explicado por uma combinação de fatores envolvendo disponibilidade de energia e de proteína para o animal. 0 aumento da degradabilidade ruminal do amido, tem se mostrado vantajoso no sentido de maximizar a capacidade fermentativa do rúmen, aumentando a síntese de proteína microbiana e a produção de ácidos 
graxos voláteis (AGVs), particularmente ácido propiônico, o principal precursor gluconeogênico em ruminantes. O resultado pode ser um maior fluxo líquido de energia na veia porta, um aumento na síntese de glicose pelo fígado e maior disponibilidade de aminoácidos para a síntese de proteína nos tecidos musculares de bovinos de corte ou na glândula mamaria de vacas leiteiras (Huntington, 1997; Theurer, 1995 e 1999).

As fontes de amido mais comumente utilizadas na nutrição animal são os grãos de cereais como, milho, sorgo, cevada e trigo. 0 milho sempre ocupou lugar de destaque, não só pelo seu comprovado valor nutritivo, como também, pela tradição de cultura em nosso país. Vale ressaltar que o amido representa cerca de $70 \%$ da matéria seca na maioria dos grãos de cereais, constituindo-se desta forma na fonte primária de energia nas dietas fornecidas para os ruminantes com o objetivo de se obter altas produções (Theurer, 1986). Pelo fato das dietas para bovinos confinados visando ganhos de peso elevado, conterem aproximadamente 40 a $60 \%$ de amido na matéria seca, fica evidente a importância da utilização eficiente desse nutriente pelo animal.

O processamento de grãos de milho e/ou sorgo através da floculação, promove alterações químicas e físicas nas moléculas do amido, facilitando a digestão por parte das enzimas amilolíticas dos 
microrganismos e/ou pancreáticas, resultando em um significativo aumento da degradação do amido, tanto no rúmen quanto no trato digestivo total, melhorando a utilização destes grãos pelos animais e conseqüentemente, melhorando o seu desempenho.

Trabalhos conduzidos com o objetivo de testar fontes protéicas de diferentes degradabilidades ruminais, para novilhos confinados com dietas com alta proporção de concentrado, as quais são ricas em amido e ou açucares, têm em muitos casos, mostrado vantagens das fontes ricas em proteína degradável no rúmen (Zinn \& Shen, 1998). Estes autores observaram melhor desempenho de novilhos de corte em crescimento, quando suplementados com uréia, em comparação ao farelo de soja ou farinha de peixe.

Knaus et al. (2001) relataram que a suplementação de novilhos de corte, com uma mistura de fontes protéicas de origem animal, balanceada em aminoácidos de acordo com o nível 2 do NRC (1996), não resultou em melhor eficiência de uso do $\mathrm{N}$ em comparação com a uréia, em dietas ricas em amido.

Um levantamento feito por Galyean (1996), mostrou que na maioria dos confinamentos americanos, as dietas de terminação, normalmente ricas em amido, contêm entre 12,5 a 14,4\% de proteína bruta, sendo que os suplementos protéicos, são preferencialmente fontes ricas em proteína degradável no rúmen, especialmente uréia, 
adicionada em torno de 0,5 a $1,5 \%$ da matéria seca da dieta. Fontes ricas em proteína não degradável no rúmen, raramente são utilizadas.

Com o objetivo de maximizar a disponibilidade de energia e proteína para ruminantes, alguns estudos têm sido propostos na tentativa de se obter uma sincronização ideal entre as taxas de degradação ruminal das fontes energéticas e protéicas, mas infelizmente, o número de trabalhos publicados sobre o assunto ainda é incipiente.

O presente trabalho teve como objetivo determinar o efeito da tentativa de sincronização da degradação ruminal de proteína e amido através da combinação entre fontes protéicas (uréia $x$ farelo de soja) e fontes de amido (milho moído x milho floculado $360 \mathrm{~g} / \mathrm{L}$ ) com níveis variáveis de degradabilidade ruminal, tentando-se maximizar a fermentação ruminal, a síntese de proteína microbiana no rúmen e a digestibilidade dos nutrientes no trato digestivo de novilhos Nelore em terminação. Os parâmetros avaliados foram: o consumo de alimento, os parâmetros ruminais (AGVs, $\mathrm{pH}, \mathrm{N}-\mathrm{NH}_{3}$ ) e a digestibilidade da MS, MO, PB, FDN, FDA e do amido, no trato digestivo total. Também era objetivo deste estudo avaliar a digestibilidade da MS, MO, PB, FDN, FDA e do amido, no rúmen e no pós rúmen, assim como síntese de proteína microbiana e fluxo de aminoácidos para o intestino. Entretanto, estas últimas avaliações foram comprometidas pela pobre recuperação do 
marcador óxido de cromo, na digesta duodenal dos bovinos alimentados com milho moído fino. 


\title{
2 REVISÃO DE LITERATURA
}

\author{
2.1 Fontes de amido
}

\subsubsection{Caracterização da molécula de amido}

O amido é um polissacarídeo heterogêneo composto de dois principais tipos de moléculas ou polímeros: amilose e amilopectina, unidas por pontes de hidrogênio (Kotarski et al., 1992; Rooney \& Pflugfelder, 1986; Van Soest, 1994). A amilose é um polímero linear de unidades de $D$-glucose unidas por ligações tipo $\alpha-1,4$, sendo que a proporção de amilose no grânulo de amido pode variar de 14 a $34 \%$ (Kotarski et al., 1992). Segundo estes autores essa variação na proporção de amilose vai depender da espécie do grão de cereal e das variações genéticas dentro das espécies. Já a amilopectina é um polímero ramificado, consistindo de uma cadeia linear de resíduos de 
glucose $(\alpha-1,4)$, com pontos de ramificações $\alpha-1,6$ a cada 20 a 25 unidades, portanto, bem maior que a amilose, correspondendo a cerca de 70 a $80 \%$ da maioria do amido contido nos grãos de milho e sorgo.

Os grânulos são pseudocristais que possuem regiões organizadas (cristalinas) e não organizadas (amorfas). A região cristalina ou micelar é primariamente composta de amilopectina, resistente a entrada de água e ao ataque enzimático do grânulo de amido. A região amorfa do amido é rica em amilose e menos densa que a cristalina, permitindo um movimento livre de água (Rooney \& Pflugfelder, 1986). O ataque das amilases aos grãos de amido é iniciado na região amorfa, enquanto que a hidrólise da região cristalina ocorre mais vagarosamente (Rooney \& Pflugfelder, 1986).

A relação amilose:amilopectina influencia a degradabilidade do amido. Guibot \& Mercier (1985) demonstraram que o amido "seroso", de baixa amilose, é mais degradável que o amido de milho comum. A menor digestibilidade das variedades de alta amilose pode estar relacionada com a capacidade da amilose de limitar a "incubação e/ou devido à orientação das moléculas de amilose em direção ao interior dos cristais de amilopectina, causando um aumento nas ligações de hidrogênio, o que limitaria o "inchaço" e a hidrólise enzimática. A outra teoria que explica a menor digestibilidade da amilose reside no fato de 
que a mesma está localizada principalmente na região amorfa onde é complexada com lipídeos (Rooney \& Pflugfelder, 1986).

O amido é o polissacarídeo de reserva da maioria das plantas e representa $70 \%$ da matéria seca da maioria dos cereais como milho, sorgo, cevada, trigo e aveia (Rooney \& Pflugfelder, 1986). Por representar 40 a $60 \%$ da matéria seca das dietas de novilhos confinados com dietas de alto desempenho, a utilização eficiente do amido é fundamental para se maximizar a produção animal (Theurer, 1986; Theurer, 1992). Um dos principais fatores que afetam a utilização do amido pelos animais é a presença de uma matriz protéica ao redor do grânulo de amido, a qual dificulta a ação das enzimas digestivas (Kotarski et al., 1992). A presença dessa matriz protéica é mais significativa nos grãos de sorgo e milho que nos demais cereais (Sniffen et al., 1987).

O grão inteiro, com o pericarpo intacto, é altamente resistente à digestão pelos ruminantes, por não permitir a adesão de bactérias (Beauchemin et al. 1994; McAllister et al. 1994), assim como por possuir uma matriz protéica intacta ao redor dos grânulos de amido. Visando aumentar a susceptibilidade da molécula de amido ao ataque enzimático no rúmen e nos intestinos, várias formas de processamento de grãos vêm sendo estudadas. 


\subsubsection{Processamento dos grãos de cereais}

Os métodos de processamento geralmente estão associados com a melhoria na eficiência da utilização dos grãos e podem ser divididos em processos físicos e químicos (Nocek \& Tamminga, 1991). O processamento físico dos grãos através da ação mecânica consiste na quebra, moagem, trituração ou peletização de grãos secos facilitando a adesão de microrganismos aos grãos de amido. Já as modificações físico-químicas envolvem a aplicação de calor, água e pressão, os quais hidratam e incham as estruturas amorfas e cristalinas dos grãos de amido. Estas alterações na estrutura do grânulo de amido aumentam a digestão amilolítica por parte das enzimas de microrganismos ruminais, como também das enzimas pancreáticas no intestino delgado. $\mathrm{O}$ processamento físico na presença de umidade e vapor quebra a matriz e corpos protéicos, que dificultam a digestão do amido, permitindo uma maior digestão enzimática (Nocek \& Tamminga, 1991).

A floculação de grãos de cereais consiste na incubação do grão em uma câmara ou compartimento, onde o mesmo fica exposto ao calor e umidade (vapor) à pressão atmosférica por 30 a 60 minutos. Durante este processo, os grãos de amido sofrem gelatinização, uma vez que absorvem água, incham, exsudam parte da amilose e se tornam mais 
susceptíveis à degradação enzimática. A gelatinização começa na região amorfa e a penetração do calor e umidade na região cristalina ocorre mais vagarosamente. $O$ processo é sinérgico, no que o estresse gerado pelo inchaço da região amorfa ajuda na quebra dos cristais. Prensando o grão quente e úmido em rolos reguláveis, quebra-se o grão inchado, formando uma pasta que se torna um floco. Isto causa um aumento na superfície de contato e na susceptibilidade do amido ao ataque enzimático, pois a matriz protéica é rompida. Sabe-se que a ruptura dessa matriz protéica é de grande importância na degradabilidade ruminal do amido (Rooney \& Pflugfelder, 1986). A maioria dos métodos de processamento aumentam a digestibilidade do amido no rúmen, o que usualmente aumenta a digestibilidade do amido no intestino delgado e conseqüentemente no trato digestivo total (Owens et al. 1986).

O grau de floculação e gelatinização do amido são determinados pelo tempo de exposição ao vapor, temperatura, umidade do grão, tipo de grão e principalmente a distância entre os rolos. Para vacas leiteiras consumindo dietas contendo entre 25 a $30 \%$ de amido total, a densidade recomendada do floco é de $360 \mathrm{~g} / \mathrm{l}$ segundo Santos et al., 1997 e Theurer et al.,1999, enquanto Plascencia \& Zinn,(1996) sugeriram entre 320 e $360 \mathrm{~g} / \mathrm{l}$. Para novilhos de corte recebendo dietas 
ricas em concentrado, valores entre 283 a $360 \mathrm{~g} / \mathrm{l}$ têm sido sugeridos (Swingle et al.,1999; Zinn, 1997; Huntington, 1997)

Em ruminantes, o amido pode ser fermentado no rúmen e no intestino grosso por microrganismos, ou digerido enzimaticamente no intestino delgado, entretanto, o principal sítio de digestão é o rúmen (Simas, 1997; Theurer, 1986; Theurer, 1991). Uma maior proporção do amido é digerida no rúmen quando o grão de milho é processado na forma floculada, comparado com o grão moído ou laminado a seco (Theurer, 1986). Os produtos finais da degradação (fermentação) ruminal do amido são acetato, propionato e butirato, os quais são denominados de ácidos graxos voláteis (AGVs). O subseqüente metabolismo dos AGVS se constituem na maior fonte de energia para os ruminantes, podendo representar até $80 \%$ dos requerimentos energéticos diários dos animais (Bergman, 1990; Van Soest, 1994). Além da geração de energia, a fermentação ruminal de carboidratos é essencial para a nutrição protéica do ruminante, devido à importância quantitativa e qualitativa da proteína microbiana.(Santos, 1996).

Histov et al. (2001) observaram redução no pH e amônia e aumento na concentração de propionato no fluido ruminal, quando a dieta continha alta concentração de uma fonte rica em amido degradável como o grão de cevada moído, indicando elevada taxa de fermentação ruminal e maior síntese microbiana. 
Lozano et al. (2000) trabalhando com grão de sorgo floculado fornecido em dietas de alto concentrado para novilhos de corte em crescimento, observaram que um grau mais intenso de processamento (menor densidade) alterou a distribuição de nutrientes precursores de energia no intestino e fígado. A redução da densidade do grão de 437 $\mathrm{g} / \mathrm{l}$ para $283 \mathrm{~g} / \mathrm{I}$, aumentou linearmente a disponibilidade de precursores de glucose (aumentando a absorção de propionato e lactato), resultando em um aumento linear na síntese de glucose pelo fígado e conseqüentemente, na disponibilidade da mesma para os tecidos extrahepáticos. Segundo os mesmos autores, esta melhora na disponibilidade de glucose pode explicar em parte, uma melhor eficiência no ganho de peso de novilhos recebendo grãos de sorgo floculado com densidade de $360 \mathrm{~g} / \mathrm{l}$ em relação ao com maior densidade (processado menor intensamente).

Alio et al. (2000) utilizaram dietas com alto teor de concentrado, tendo o farelo de soja como fonte protéica e testaram diferentes densidades de grãos de sorgo floculado como fonte de energia para novilhos de corte em crescimento, implantados cirurgicamente com cateteres na artéria mesentérica e nas veias porta, mesentérica e hepática. Estes autores observaram que houve um aumento linear no fluxo líquido de aminoácidos na veia porta e na reciclagem de nitrogênio plasmático para o rúmen, com a floculação do grão de sorgo assim 
como com um aumento na intensidade da floculação. Segundo estes autores, estas mudanças metabólicas podem em parte, explicar o melhor desempenho de novilhos recebendo grãos floculados, publicados na literatura. Uma ótima densidade de grãos para uma maior disponibilidade de nutrientes pós-absorção foi de $283 \mathrm{~g} / \mathrm{l}$, a qual é menor do que os valores ótimos publicados (aproximadamente $360 \mathrm{~g} / \mathrm{l}$ ) em estudos de desempenho.

Beauchemin et al. (2001) em um experimento com grãos de cevada para novilhos de corte observaram que as digestibilidades de amido e matéria orgânica (MO) aumentaram linearmente com o processamento do grão, assim como o fluxo de $\mathrm{N}$ microbiano para o duodeno também foi maior com o grão mais processado.

Castillo et al.(b) (2001) trabalhando com fontes de energia para vacas leiteiras, observaram que a quantidade e a forma de $\mathrm{N}$ excretado podem ser manipulados pela mudança na fonte de energia do concentrado, sem que haja efeitos na qualidade ou produção de leite.

Huntington (1994 e 1997) revisando trabalhos de pesquisa realizados desde 1986, encontrou subsídios suficientes para afirmar que a fonte ou tipo do grão e o método de processamento deste grão têm grande influência no sítio (rúmen ou intestinos) e na extensão de digestão do amido, assim com anteriormente relatado por Owens (1986) e Theurer (1986). Os métodos de processamento, como a floculação e os 
grãos de alta umidade, aumentam a digestibilidade ruminal do amido do milho e sorgo, entretanto, a cevada, trigo e aveia não se beneficiam tanto com o processamento, pois nestes os valores de digestibilidade ruminal já são naturalmente elevados, mesmo quando pouco processados.

Huntington (1997) sumarizou 23 trabalhos de pesquisa e encontrou os seguintes coeficientes médios de digestibilidade ruminal para o amido de diferentes tipos de grãos: milho laminado a seco $75,3 \%$ \pm 7.9 , sorgo laminado a seco $59,8 \% \pm 11,2$, cevada laminada a seco $80,7 \% \pm 3,9$, trigo laminado a seco $88,8 \%$ e aveia laminado a seco $92,7 \%$. O mesmo autor encontrou os seguintes coeficientes médios de digestibilidade ruminal para o amido de diferentes tipos de grãos floculados: milho floculado $84,8 \% \pm 4,1$ e sorgo floculado $79 \% \pm 3,6$, enquanto a cevada laminada a vapor apresentou valores de $84,6 \%$, o trigo laminado a vapor $88,1 \%$ e a aveia laminada a vapor $94 \%$. Observase que os maiores benefícios do processamento ocorreram para o milho e sorgo, os quais possuem uma matriz protéica mais intensa, sendo a do sorgo, maior que a do milho (Sniffen, 1980; Spicer et al., 1986; Rooney e Pflugfelder, 1986; Theurer, 1986).

Segundo Hale (1973) a quebra desta matriz protéica, principalmente no grão de sorgo, é importante para uma maior utilização do amido, já que a digestibilidade da proteína e amido 
parecem estar diretamente relacionadas. Rooney \& Miller (1982) e Teixeira (1997) também reportou a importância do processamento na degradabilidade do amido do milho e sorgo.

\subsubsection{Digestão e metabolismo de amido pelos tecidos esplânicos}

Vários gêneros de bactérias ruminais têm sido identificadas como sendo amilolíticas: Bacterioides, Eubacterium, Streptococcus, Butyrivibrio, Ruminobacter, Selenomonas, Succinovibrio, Succinomonas e Lactobacillus (Kotarski et al., 1992; Van Soest, 1994). Entretanto, as mais importantes espécies amiloliticas são Bacteroides amylophilus, Streptococus bovis, Succinomonas amylolitica, Bacteroides ruminicola e algumas estirpes de Bacteroides succinogenes. Essas bactérias tendem a predominar no rúmen de animais alimentados com dietas ricas em grãos (Yokoyama \& Johnson, 1988). A degradação ruminal do amido pelas bactérias amilolíticas envolve uma enzima denominada $\alpha$-amilase extracelular, a qual cliva aleatoriamente a molécula de amido (Yokoyama \& Johnson, 1988). Após o amido ser degradado a maltose e glucose, as bactérias sacarolíticas irão fermentar esses substratos rapidamente até piruvato. Dois moles de piruvato são produzidos para cada hexose, com 
a produção concomitante de duas adenosinas tri-fosfato (ATP) e de dois $\mathrm{NADH}_{2}$. O ATP gerado é a principal fonte de energia para o crescimento e mantença das bactérias ruminais (Fahey \& Berger, 1988).

O Piruvato é o caminho intermediário pelo qual todos os carboidratos têm que passar antes de serem convertidos a $\mathrm{AGVs}, \mathrm{CO}_{2}$ e metano. A proporção molar de AGVS ( $\mu \mathrm{mol})$, bem como, as proporções molares de acetato, propionato e butirato produzidos no rúmen dependem do tipo de carboidrato fermentado no rúmen, tempo e extensão da degradação, espécie de bactéria e ambiente ruminal (Bergman, 1990; Van Soest, 1994). Dietas ricas em grãos tendem a produzir maior proporção molar de ácido propiônico em relação a dietas ricas em carboidratos estruturais. Quando a degradabilidade do amido no rúmen foi aumentada através da floculação do sorgo ou através da utilização de milho grão de alta umidade, a proporção de propionato em relação ao total de AGVS aumentou 20\% (Moore et al., 1992; Oliveira et al., 1993) e 14,7\% (Lykos et al., 1997), respectivamente. Plascencia \& Zinn et al. (1996) e Joy et al. (1997) reportaram que quando comparado ao milho laminado a seco, o milho floculado, aumentou a proporção molar de propionato e reduziu a proporção molar de acetato. Plascencia \& Zinn et al. (1996) ainda observaram que houve efeito linear no decréscimo da proporção molar de acetato quando a densidade do floco diminuiu (390g// até $260 \mathrm{~g} / \mathrm{l})$. Hristov et al. (2001) fornecendo dietas 
com grãos de cevada para novilhos observaram que a concentração de AGVs totais e propionato foram maiores em dietas com alto teor de concentrado.

O rúmen também contém uma população de protozoários, os quais podem proporcionar certo impacto na digestão de carboidratos através da ingestão de grânulos de amido, açúcares solúveis e pequenas partículas de plantas as quais são digeridas internamente. Esta ingestão pelos protozoários pode alterar a taxa e a extensão da fermentação do amido pela diminuição da disponibilidade desse substrato para o rápido crescimento bacteriano (Kotarski et al., 1992). Outro fator seria a ingestão de bactérias em número suficiente para diminuir a taxa de fermentação ruminal. Entretanto, dietas ricas em grãos freqüentemente levam a uma queda brusca de $\mathrm{pH}$ e como os protozoários são muito sensíveis a $\mathrm{pH}$ abaixo de 6,0, não estão fortemente envolvidos em alguma apreciável extensão na modulação da taxa de fermentação de amido em ruminantes alimentados com dietas ricas em grãos.

Quase a totalidade dos AGVS produzidos pelo processo fermentativo ruminal são absorvidos passivamente através do epitélio rúmen-retículo e abomaso, sendo o rúmen-retículo, responsável por 88\% dos AGVS absorvidos (Bergman, 1990). Reynolds \& Huntington (1988) reportaram que em animais alimentados com concentrado 
peletizado com grão de milho, 85 a $100 \%$ do fluxo de AGVS na veia porta, era proveniente da fermentação ruminal.

Parte dos AGVS, durante o processo de absorção, são metabolizados pelo epitélio ruminal e o percentual de AGVS a ser metabolizado, aumenta com o tamanho da cadeia e com a atividade das enzimas CoA sintetase nos diferentes tecidos. Portanto, $90 \%$ do butirato produzido é metabolizado pelo epitélio ruminal sendo oxidado a $\mathrm{CO}_{2}$ e corpos cetônicos ( $ß$ - hidroxibutirato, acetona e acetoacetato), ou seja, somente $10 \%$ do butirato produzido no rúmen chegam ao fígado. Isto demonstra uma alta atividade da enzima Butiril CoA Sintetase no epitélio ruminal. Já o propionato é bem menos metabolizado pelo epitélio ruminal de vacas leiteiras, cerca de 3 a $15 \%$, os quais são oxidados a $\mathrm{CO}_{2}$, lactato e alanina; e o restante ( $>80 \%$ do que é produzido) chega ao fígado. Ao redor de $95 \%$ do fluxo líquido de propionato na veia porta, é convertido em glucose no fígado, indicando uma alta atividade hepática da enzima Propionil CoA Sintetase. O propionato, como relatado anteriormente, é o maior precursor gluconeogênico em ruminantes. Já o acetato, é pouco metabolizado tanto pelo epitélio ruminal como pelo fígado. Isso explica o fato de cerca de 90 a $98 \%$ dos AGVs encontrados na circulação arterial e venosa periférica ser acetato, demonstrando uma baixíssima atividade da enzima Acetil CoA Sintetase no epitélio ruminal e hepático. Somente 3\% do turnover é utilizado pelo 
fígado, sendo metabolizado principalmente pelos tecidos periféricos (adiposo e muscular) onde a atividade da enzima Acetil CoA Sintetase é muito alta (Bergman, 1990).

\subsection{Proteína}

2.2.1 Síntese de proteína microbiana e fermentação ruminal

A fermentação ruminal é o resultado de atividades físicas e microbiológicas, as quais convertem componentes da dieta em produtos que são utilizados (AGVS, proteína microbiana, vitaminas do complexo B), ou não (metano e gás carbônico) pelos animais hospedeiros (Owens, 1988; Van Soest, 1982 e Van Soest, 1994).

A proteína ingerida pelo ruminante pode passar para o abomaso sem sofrer ação dos microrganismos ou ser degradada no rúmen, onde as ligações peptídicas são hidrolisadas (proteólise) e os peptídeos e AA liberados são utilizados para a síntese de proteína microbiana (PM) ou deaminados, produzindo amônia e ácidos graxos voláteis (AGV) (Santos et al., 1998). 
A extensão de degradação da proteína é variável entre os ingredientes da dieta e depende do tempo de retenção no rúmen, o qual diminui com a redução do tamanho da partícula. A taxa de degradação intrínseca a cada alimento também pode ser alterada pelos métodos de processamento, tais como peletização, extrusão, laminação, floculação e tostagem (Clark et al., 1992).

Segundo Owens \& Zinn (1988), os microrganismos ruminais geralmente contém entre 40 e $60 \%$ de sua MS na forma de PB, sendo que as bactérias possuem em média $50 \%$ ( $\pm 5 \%$ ) de PB na MS e os protozoários ao redor de $40 \%$ ( $\pm 20 \%)$. Para as bactérias, a fonte de $\mathrm{N}$ para a síntese protéica pode ser oriunda da proteína da dieta ou de NNP (dietético ou proveniente da reciclagem), ao passo que os protozoários não utilizam NNP como fonte de N.

A produção de proteína microbiana é resultado da eficiência microbiana ( $\mathrm{g}$ de nitrogênio de origem bacteriana / kg de matéria orgânica verdadeiramente digerida no rúmen) multiplicada pela quantidade $(\mathrm{kg})$ de matéria orgânica verdadeiramente digerida no rúmen (MOVD) (Sniffen et al. 1992). Pelo simples fato de que a proteína e os lipídios estão contidos na matéria orgânica e os mesmos contribuem com muito pouca energia (ATP) para os microrganismos, vários estudos têm sugerido que o mais apropriado seria expressar a eficiência microbiana como função da digestão de carboidratos no rúmen. Desta 
forma, a produção microbiana ( $\mathrm{gN}$ ) passa a ser resultado da quantidade de substrato fermentado no rúmen (carboidrato) e da eficiência microbiana ( $\mathrm{gN} / \mathrm{kg}$ de carboidrato fermentado) (Russel et al. 1992).

No rúmen as bactérias requerem fontes de $\mathrm{N}$, energia, minerais, vitaminas e outros nutrientes para crescer. Contudo, $\mathrm{N}$ e energia são requeridos em quantidades maiores e exercem maior influência no crescimento bacteriano. Quando a proteína é degradada mais rapidamente do que a fonte de energia, ocorre um desacoplamento da fermentação, aumentando a concentração de amônia ruminal, que é absorvida pela parede do rúmen e é convertida em uréia no fígado (Norlan, 1975). Essa uréia pode ser reciclada via saliva ou parede do rúmen, mas a maior proporção é excretada na urina. Norlan (1975) notificou em seus estudos que mais de $25 \%$ da proteína de origem alimentar é perdida na forma de amônia ruminal. Contrariamente, quando grande quantidade de energia é degradada, ultrapassando a velocidade de degradação da proteína, o crescimento microbiano e a eficiência digestiva decrescem. Isto é caracterizado pela fermentação incompleta, onde os microrganismos, deficientes em $\mathrm{N}$, desviam ATP para o acúmulo de carboidrato e não para a síntese de proteína microbiana (Nocek \& Russel, 1988).

Cameron et al. (1991) observaram que a síntese de proteína microbiana e o crescimento microbiano depende de uma adequada 
quantidade de energia e $\mathrm{N}$ para a síntese e assimilação de aminoácidos. Um sincronismo entre a degradação ruminal da proteína e carboidratos da dieta é necessária para um ótimo crescimento microbiano e síntese protéica (Russel \& Hespel, 1981). A deficiência em fontes de N (amônia, AA e peptídeos) pode limitar o crescimento microbiano e a síntese de proteína microbiana, principalmente quando dietas contendo uma alta concentração de PNDR são fornecidas (Nocek \& Russel, 1988).

Segundo Clark et al., (1992); Huber et al., (1994); Owens, (1980) e Van Soest, (1994), os principais fatores que afetam o crescimento e a eficiência das bactérias ruminais são energia e proteína, como foco primário de atenção. Entretanto, existem fatores que afetam a fermentação ruminal como: 1) pH ruminal, o qual estando abaixo de 6,2 pode deprimir o crescimento de microrganismos ruminais, principalmente bactérias celulolíticas e metanogênicas; 2) taxa de passagem, pois a eficiência de crescimento de células microbianas aumenta à medida que aumenta a taxa de diluição e as altas taxas de renovação selecionam espécies bacterianas com taxas mais rápidas de crescimento e provocam a lavagem das espécies com taxas menores de crescimento, aumentando a eficiência microbiana e, podendo até diminuir a extensão da digestão ruminal. Esses fatores são determinados pelo nível de consumo do animal, sistema de alimentação, tamanho de 
partícula, qualidade e proporção da forragem e tipo e processamento dos carboidratos dos alimentos.

Os requerimentos de nutrientes são complexos, dinâmicos e uma função dos requerimentos de mantença como também dos requerimentos para crescimento dos microrganismos. Segundo Hoover \& Stokes (1991), as principais fontes de nitrogênio para o crescimento microbiano são peptídeos, aminoácidos e amônia, estando todos disponíveis entre uma e duas horas após a alimentação, sendo que logo após este período, declinam até a próxima alimentação. Desta forma, a disponibilidade de proteína (percentual na matéria seca e fonte) pode ter um significante efeito na fermentação ruminal e síntese microbiana, pois segundo Russell et al. (1992), as bactérias ruminais requerem amônia, aminoácidos e peptídeos para o máximo crescimento. A amônia é a principal fonte de nitrogênio para os microrganismos fermentadores de carboidratos estruturais, enquanto os aminoácidos e peptídeos constituem a maior fonte de nitrogênio para os fermentadores de carboidratos não estruturais.

A quantidade de $\mathrm{N}$-amoniacal no fluido ruminal, necessária para maximizar a síntese de proteína microbiana tem sido pesquisada extensivamente. Sater \& Slyter (1974) sugeriram valores de 2$3 \mathrm{mg} / 100 \mathrm{ml}$ líquido ruminal, similares à Slyter et al. (1979), que sugeriram 2-5mg/100ml e Clark et al. (1992) que também sugeriram 
$2-5 \mathrm{mg} / 100 \mathrm{ml}$. Entretanto, valores mais altos foram sugeridos por Odle et al. (1987) em dietas com cevada laminada $(12,5 \mathrm{mg} / 100 \mathrm{ml})$ e com milho quebrado $(6,1 \mathrm{mg} / 100 \mathrm{ml})$, assim como por Meherz et al. (1977) que obtiveram valores máximos de fermentação ruminal quando os teores de $\mathrm{N}$-amoniacal foram de $22 \mathrm{mg} / 100 \mathrm{ml}$. O que parece existir de fato é que o nível ótimo de nitrogênio amoniacal ruminal varia de acordo com a disponibilidade de carboidrato fermentáveis no rúmen.

O NRC gado de corte (NRC, 1996) estabeleceu que a exigência de PDR é igual a 100\% do fluxo de proteína microbiana para o duodeno, o qual é calculado como sendo $13 \%$ do NDT da dieta. Isto significa que a exigência de PDR é aumentada à medida que se aumenta o teor de energia na dieta. Dietas para altos níveis de ganho de peso, com 70 a 74\% de NDT, exigem teores de PDR na matéria seca entre 9,5 a $10 \%$. Entretanto, o modelo não é sensível a um efeito negativo na síntese microbiana quando da deficiência de PDR. Um fator de correção para efeito de $\mathrm{pH}$ ruminal na síntese microbiana é incluído no modelo. Quando o FDN efetivo é menor que $20 \%$ da matéria seca da dieta, ocorre uma redução síntese microbiana, da ordem de 2,2\% para cada unidade percentual de redução na FDN efetiva.

O NRC gado de leite (NRC, 2001) também calcula a produção de proteína microbiana como sendo $13 \%$ do NDT, sendo que este NDT é ajustado para o consumo de matéria seca, ou seja, há uma redução na 
concentração de NDT da dieta à medida que o consumo aumenta. Nenhuma correção é feita para pH ruminal, uma vez que o NRC (2001) não adotou o conceito de fibra efetiva. Entretanto, o modelo assume uma exigência de PDR igual a 1,18 x kg de proteína microbiana. Quando a disponibilidade de PDR é inferior a este valor, a síntese de proteína microbiana é calculada como $85 \%$ da quantidade de PDR da dieta.

Devant et al. (2001) observaram que a síntese de proteína microbiana foi menor quando novilhos de corte receberam dieta rica em proteína não degradável no rúmen (PNDR), indicando que a disponibilidade de nitrogênio limitou o crescimento microbiano. Os autores também observaram que a eficiência da síntese de proteína microbiana aumentou no tratamento que recebeu uréia. Segundo Fu et al. (2001), a produção de $\mathrm{N}$ bacteriano aumentou linearmente com a proteína degradável no rúmen (PDR), mas a eficiência microbiana não foi afetada.

A relação concentrado:volumoso pode afetar tanto e eficiência quanto a produção microbiana devido aos efeitos na disponibilidade de substrato, taxa de passagem e pH ruminal (Russel et al. 1992). Segundo Rode et al. (1985), a eficiência microbiana foi maior quando a proporção volumoso:concentrado foi de 80:20 (feno de alfafa:milho+farelo de soja), mas a produção microbiana foi maior nas dietas que continham maior proporção de concentrado (38:62). 
Estudos de metabolismo têm comparado diferentes fontes de grãos com diferentes degradabilidades ruminais. McCarthy et al. (1989) compararam milho moído e cevada laminada a vapor, e observaram que a cevada laminada tendeu a aumentar a síntese microbiana no rúmen, porém sem nenhum efeito na eficiência microbiana. Beauchemin et al. (2001) utilizando novilhos de corte para comparar tipos de processamento em grãos de cevada, relataram que grãos menos processados não são recomendados, pois resultam em uma menor digestibilidade e menor síntese de proteína microbiana. Spicer et al. (1986) compararam sorgo laminado a seco, milho laminado a seco e cevada floculada em novilhos de corte canulados, recebendo dietas com $80 \%$ de grão, e observaram que o fluxo de nitrogênio microbiano para o duodeno foi maior para o tratamento com cevada.

Quando a degradabilidade ruminal do amido de sorgo foi aumentada através do processo de floculação, a eficiência microbiana não foi afetada, entretanto, a passagem de proteína microbiana para o duodeno foi maior comparada com o sorgo laminado a seco (Oliveira et al. 1995; Poore et al. 1993), devido à maior disponibilidade de substrato fermentável no rúmen.

Plascencia \& Zinn (1996) compararam milho laminado a seco e milho floculado com várias densidades (390, 320 e 260g/litro) e observaram maior quantidade de nitrogênio microbiano passando para o 
duodeno e maior eficiência microbiana, nos tratamentos que continham milho floculado em relação ao tratamento milho laminado. Entretanto, Joy et al. (1997) comparando milho laminado a seco (540 g/l) com milho floculado $(390,310 \mathrm{~g} /$ litro) não encontraram efeito do processamento sobre a eficiência microbiana nem no fluxo de nitrogênio microbiano para o duodeno. O mesmo aconteceu com Lycos et al. (1997) que trabalharam com diferentes taxas de degradação de carboidratos não estruturais.

Hoover \& Stockes (1991) observaram grande síntese de proteína microbiana quando as vacas de leite se alimentaram com dietas contendo altas proporções de carboidratos não estruturais e proteína degradável no rúmen (38 e 13,2 ou 31 e 11,8\%, respectivamente, na matéria seca da dieta) comparado com dietas contendo baixos teores de carboidratos não estruturais e proteína degradável no rúmen (24 e 9\%, respectivamente).

Aldrich et al. (1993) observaram alto fluxo de proteína microbiana para o duodeno quando as vacas em lactação se alimentaram com uma dieta alta em amido degradável no rúmen (milho alta umidade) combinada com fontes de proteína de alta degradabilidade ruminal (farelo de soja). Desta forma, acredita-se que nitrogênio e energia são requeridos em grandes quantidades, mas precisam estar disponíveis de 
maneira balanceada e com suas degradabilidades sincronizadas para maximizar o crescimento bacteriano.

Herrera Saldana et al. (1990) observaram efeito positivo da sincronização de fontes de proteína e amido na fermentação ruminal, síntese microbiana e desempenho de vacas em lactação.

O maior fluxo de proteína para o duodeno em vacas recebendo sorgo floculado comparado com sorgo laminado, pode ser atribuído ao aumento na síntese de proteína microbiana, devido a maior digestibilidade do amido e melhor sincronização com a proteína degradada no rúmen (Poore et al., 1993)

O aumento na síntese de proteína microbiana pode melhorar a quantidade e o perfil de aminoácidos essenciais (AAE) que chegam ao duodeno para serem absorvidos, resultando especialmente em mais lisina e metionina o que pode favorecer o desempenho de novilhos de corte (Zinn \& Shen, 1998).

O NRC gado de corte (NRC, 1996) expressa as exigências protéicas na forma de proteína metabolizável, a qual é definida como sendo a proteína verdadeira digerida pós-rúmen e os aminoácidos componentes absorvidos pelo intestino. A proteína metabolizável é oriunda da digestão intestinal da proteína microbiana e da proteína dietária não degradável no rúmen (PNDR). A necessidade de ingestão de proteína bruta é estimada como sendo a quantidade de proteína 
degradável no rúmen (PDR) necessária para o crescimento microbiano, mais a PNDR necessária para complementar o requerimento de proteína metabolizável para mantença e ganho que não foi atingido pela proteína de origem microbiana.

O NRC gado de leite (NRC, 2001) computa os aminoácidos provenientes da digestão da proteína endógena, além dos provenientes da proteína microbiana e PNDR, para o cálculo de proteína metaboizável.

Beauchemin et al. (2001) observaram que a digestibilidade ruminal da proteína bruta não diferiu, mas tendeu a aumentar no trato total em dietas com grãos mais processados.

O crescimento microbiano e a síntese protéica podem ser estimulados por uma fermentação ruminal saudável (Sniffen \& Robinson, 1987) e pela diminuição da extensão dos distúrbios causados ao ambiente ruminal pelo manejo alimentar incorreto (Robinson, 1989). Uma das formas possíveis de se conseguir tal objetivo é através da sincronização da degradação de proteína e da matéria orgânica (MO) no rúmen (DePeters \& Cant, 1992; Russel \& Hespell, 1981).

Hoover \& Stockes (1991) compilaram informações de vários estudos em curvas de estimativa com o objetivo de quantificar os requerimentos e a degradabilidade de carboidratos em relação ao nível de degradabilidade da proteína e sugeriram que o sincronismo foi importante na eficiência produtiva de ruminantes. 
Russel et al. (1983) concluíram que a disponibilidade de carboidrato reduziu o acúmulo de amônia no rúmen quando avaliaram o efeito da limitação de carboidrato na degradação e utilização da caseína pelas bactérias ruminais.

Em alguns trabalhos publicados, foram observados efeitos positivos quando se procurou aliar a alta degradabilidade ruminal de fontes de amido e de proteína nas dietas de vacas leiteiras. Nestes estudos, os efeitos positivos foram uma maior produção de leite (Herrera-Saldana \& Huber, 1989), estímulos à produção de proteína microbiana no rúmen (Herrera-Saldana et al., 1990) e maior eficiência de utilização do $\mathrm{N}$ para a síntese microbiana (Moore et al., 1992).

Apesar da aceitação geral do conceito de sincronização da degradação ruminal entre proteína e amido, poucos trabalhos têm sido conduzidos com gado de corte para se compreender melhor o assunto. Esta técnica propõe incrementar a produção microbiana no rúmen e a eficiência de utilização dos nutrientes, uma vez que as bactérias ruminais necessitam destes dois elementos disponíveis ao mesmo tempo, apesar de em concentrações diferentes. A fermentação dos carboidratos possui uma larga influência na utilização de $\mathrm{N}$ pelo rúmen e no crescimento microbiano aumentando a importância da sincronização da degradação ruminal destes dois nutrientes (Huber \& Herrera-Saldana, 1990). 


\subsubsection{Fontes Protéicas}

As fontes protéicas variam quanto à solubilidade ruminal bem como quanto à taxa de degradação. A adequação da dieta em proteína degradável no rúmen (PDR), é fundamental para maximizar a atividade microbiana e conseqüentemente a produção de proteína microbiana. Dentre as fontes protéicas existentes no Brasil, o farelo de soja, o farelo de algodão e a uréia são as mais utilizadas na formulação das dietas de bovinos confinados.

O farelo de soja convencional (FS) apresenta baixo teor de proteína não degradável no rúmen de acordo com as tabelas do NRC (1985; 1996), e por ser um dos suplementos protéicos mais comum nas rações para bovinos em diversos países desenvolvidos, tem sido usado como a fonte protéica básica a ser comparada com outras fontes de proteína (Santos et al., 1998).

Devant et al. (2000) observaram que novilhos, recebendo dietas com diferentes teores protéicos e variando também a degradabilidade da proteína, não apresentaram diferenças no ganho de peso diário, nem na ingestão de matéria seca. Mas os animais que receberam a dieta com 17\% de PB tiveram uma maior excreção de uréia pela urina, sugerindo um excesso de $\mathrm{N}$ na dieta. 
De acordo com o NRC (1996) o a quantidade de N que chega no intestino delgado (ID) é influenciada principalmente pela ingestão de proteína bruta e pelo ingestão de energia fermentável, e é a somatória da combinação entre proteína microbiana (PMic), PNDR e proteína endógena, apesar desta última não ser considerada nos cálculos. A composição de aminoácidos (AA) destas fontes e a proporção de cada uma delas na proteína total que chega ao intestino determinam a quantidade e perfil de AA passíveis de serem absorvidos O conjunto de aminoácidos (AA) provenientes da digestão e passíveis de absorção no intestino delgado, compõe o que se denomina de proteína metabolizável,.

O NRC (1996) trouxe como uma das principais inovações no quesito balanceamento protéico, em relação às versões anteriores, a adequação da dieta em termos de proteína metabolizável e PDR, ao invés da simples adequação em proteína bruta. Além desses aspectos, o programa também permite adequar o perfil de AA na proteína metabolizável utilizando o nível 2 do programa.

De modo geral, quando se utiliza o NRC (1996) tanto no nível 1 como no 2, para novilhos em terminação, recebendo dietas ricas em amido, a utilização de uréia como único suplemento protéico, já permite adequar a dieta tanto em PDR como em proteína metabolizável. 
Segundo Devant et al. (2001), em dietas com alto teor de concentrado e baixa proteína, a baixa disponibilidade de $\mathrm{N}$ para os microrganismos, limita a síntese de proteína microbiana e a digestão de nutrientes. Neste caso, fontes ricas em PDR seriam mais adequadas para serem suplementadas, permitindo um aumento da síntese de proteína microbiana, a qual é uma fonte muito bem balanceada em aminoácidos essenciais, sendo superior a qualquer suplemento protéico comercial usado em dietas para bovinos.

Perry \& Cecava (1995) observaram que em dietas com alta proporção de alimentos concentrados à base de milho, a suplementação com altos níveis de PNDR reduziu a performance animal quando comparada à suplementação com farelo de soja. Isto ocorre devido à diminuição da concentração de nitrogênio amoniacal e talvez de aminoácidos e peptídeos no rúmen, o que limitaria a síntese microbiana. Segundo os mesmos autores, dietas suplementadas com fontes ricas em PNDR não possibilitam um aumento consistente no fluxo de aminoácidos para o intestino delgado e não refletem aumentos significativos nas taxas de crescimento e eficiência alimentar.

Loerch \& Berger (1981) não encontraram respostas evidentes na performance de novilhos recebendo dietas com nível energético médio, à base de silagem de milho e milho moído e uma fonte de PNDR, em 
comparação com os animais que receberam farelo de soja como fonte protéica.

Coomer et al. (1993) verificaram que aumentando o teor de PNDR na dieta, através da suplementação de farelo de soja tostado e farelo de glúten de milho, houve um decréscimo na concentração de $\mathrm{N}$ amoniacal no fluído ruminal e na digestibilidade da matéria seca e orgânica, porém, houve um aumento no fluxo de proteína bruta, aminoácidos e aminoácidos essenciais para o abomaso bem como uma maior absorção de aminoácidos no intestino delgado. No tocante ao desempenho dos animais, a suplementação com fontes ricas em PNDR não afetou o consumo de matéria seca, o ganho médio diário e a eficiência alimentar em novilhos e novilhas.

Nos últimos anos tem crescido a preocupação com a questão ambiental, e um dos aspectos bastante estudados tem sido, a adequação protéica da dieta de bovinos confinados, visando minimizar perdas de amônia para o ambiente. Estudos têm sido conduzidos, utilizando o NRC (1996), para checar a eficiência do modelo em termos de eficiência de uso do $\mathrm{N}$ da dieta. Castillo et al. (a) (2001) observaram que dietas com fontes de proteína de baixa degradabilidade ruminal diminuíram a excreção de $\mathrm{N}$ pela urina. Huntington et al. (2001) utilizando fontes de proteína fornecidas a novilhos em crescimento, observaram que a quantidade ou degradabilidade da proteína afeta o metabolismo de 
uréia, o que foi evidenciado pelas mudanças nas concentrações de uréia plasmática.

Fontes de nitrogênio não protéico, como a uréia, têm sido usadas em dietas com o objetivo de aumentar o nível de proteína degradável no rúmen (PDR) em substituição parcial ou total às fontes de proteína verdadeira, como farelo de soja, farelo de algodão, fontes de origem animal, etc (Santos et al., 1998).

A uréia é a fonte de nitrogênio não protéico mais utilizada na nutrição de ruminantes, devido as suas propriedades físico-químicas e pelo aspecto econômico. A uréia é prontamente degradada à amônia no ambiente ruminal, servindo como base para a síntese de proteína microbiana (Teixeira, 1992). Segundo o NRC (1996), a uréia apresenta um equivalente protéico da ordem de $291 \%$ de proteína bruta, com $100 \%$ de degradabilidade ruminal.

O uso de fontes de nitrogênio não protéico é apropriado em dietas com alto teor de grãos, devido à rápida degradação do amido no rúmen. Trabalhando com dietas contendo teores elevados de milho floculado e 10 a $11 \%$ de proteína bruta para novilhos em crescimento (249 kg), Zinn \& Shen (1998) observaram que a digestibilidade da matéria orgânica e do $\mathrm{N}$, e o fluxo de $\mathrm{N}$ microbiano para o intestino delgado foram superiores com uréia como fonte suplementar de $\mathrm{N}$ em comparação ao farelo de soja e farinha de peixe. O fluxo de aminoácidos 
essenciais (AAE) para o duodeno foi similar para dietas suplementadas com uréia ou farelo de soja. Entretanto, o ganho de peso diário e a ingestão de matéria seca foram superiores para dietas suplementadas com uréia.

Milton et al. (1997), trabalhando com novilhos de ano, suplementados com diferentes níveis de uréia na dieta, concluíram que o consumo de matéria seca e a eficiência alimentar aumentaram quando concentrações intermediárias de uréia foram utilizadas e diminuíram quando esta foi adicionada em concentrações mais elevadas. Verificaram ainda que o nível ótimo de uréia para consumo de matéria seca, ganho de peso médio diário e eficiência alimentar foi da ordem de 0,5\% da MS total, e que a uréia aumentou a utilização da energia dietária, mas não o fluxo da proteína metabolizável. Os ganhos de peso diários observados para novilhos cruzados, alimentados com dietas contendo 1,5\% de uréia, foram $9 \%$ menores que os ganhos observados para novilhos que receberam suplementação com $0,9 \%$ de uréia na dieta. Estes autores não encontraram diferenças no ganho de peso médio diário de bezerros de ano recebendo apenas uréia ou uréia mais farinha de sangue e glúten de milho como fontes protéicas, concluindo então, que fontes protéicas que escapam à degradação ruminal têm pequeno valor para animais jovens alimentados com ração à base de milho moído, provavelmente porque as 
necessidades de proteína metabolizável sejam atingidas pela fração de proteína não degradável do milho e pela fração microbiana.

Em um experimento com novilhos de corte recebendo uma dieta a base de milho moído, Shain et al. (1998) não observaram diferença na ingestão de matéria seca ou ganho de peso de novilhos suplementados com uréia em dietas com níveis crescentes de proteína bruta, em relação a dieta controle, na qual, não havia suplementação proteica. Entretanto, novilhos que receberam a suplementação de uréia na dieta foram $5.4 \%$ mais eficientes e ganharam peso $6.6 \%$ mais rápido que os novilhos não suplementados. As dietas dos animais não suplementados com uréia foram deficientes em proteína degradável no rúmen, resultando na redução da síntese microbiana. Resultados semelhantes a estes foram obtidos por Milton \& Brandt (1994 e 1995).

A taxa de degradação ruminal da fonte energética é o principal fator limitante para a utilização de NNP e a rápida degradação da uréia no rúmen pode acarretar um aumento nas concentrações de $\mathrm{N}$ amoniacal e uma alta absorção de amônia pela parede ruminal, caso não haja carboidratos fermentescíveis suficientes no rúmen. Isto irá acarretar uma sobrecarga de $\mathrm{N}$ amoniacal no fígado e um gasto maior de energia para a excreção da uréia além de risco de intoxicação. Tendo em vista este problema, existem pesquisas que vem buscando maneiras de reduzir a velocidade da hidrólise da uréia no rúmen. A liberação gradual de $\mathrm{NH}_{4}$ 
permitiria aos microrganismos ruminais uma síntese contínua de proteína microbiana sem provocar aumentos súbitos na concentração de N amoniacal (Cass et al., 1994 e Parré, 1995). Neste sentido, o produto resultante da extrusão do amido com a uréia, conhecido como amiréia, poderia trazer efeitos positivos na utilização da uréia para ruminantes. Isto foi evidenciado por Helmer (1970) quando, em experimento in vitro, notou concentrações maiores de proteína microbiana e menores de amônia no fluído ruminal com o produto, possivelmente devido a um aumento na eficiência dos microrganismos em usar a amiréia como substrato para síntese protéica. 


\section{MATERIAL E MÉTODOS}

\subsection{Animais, local e período}

Foram utilizados quatro novilhos da raça Nelore com aproximadamente 20 meses de idade e $300 \mathrm{Kg}$ de peso vivo, os quais foram submetidos à intervenções cirúrgicas para implantação de duas cânulas, sendo, uma localizada no rúmen e outra na parte proximal do duodeno.

O experimento foi conduzido nas instalações do Centro de Pesquisa em Nutrição Animal do Departamento de Produção Animal da ESALQ/USP. Os novilhos permaneceram em galpão coberto, dotado de contenções individuais $(2,5 \mathrm{~m} \times 1,00 \mathrm{~m})$, tipo "tie stall", providas de piso de borracha, comedouro individual e bebedouro automático individual (Figuras 1 e 2). 

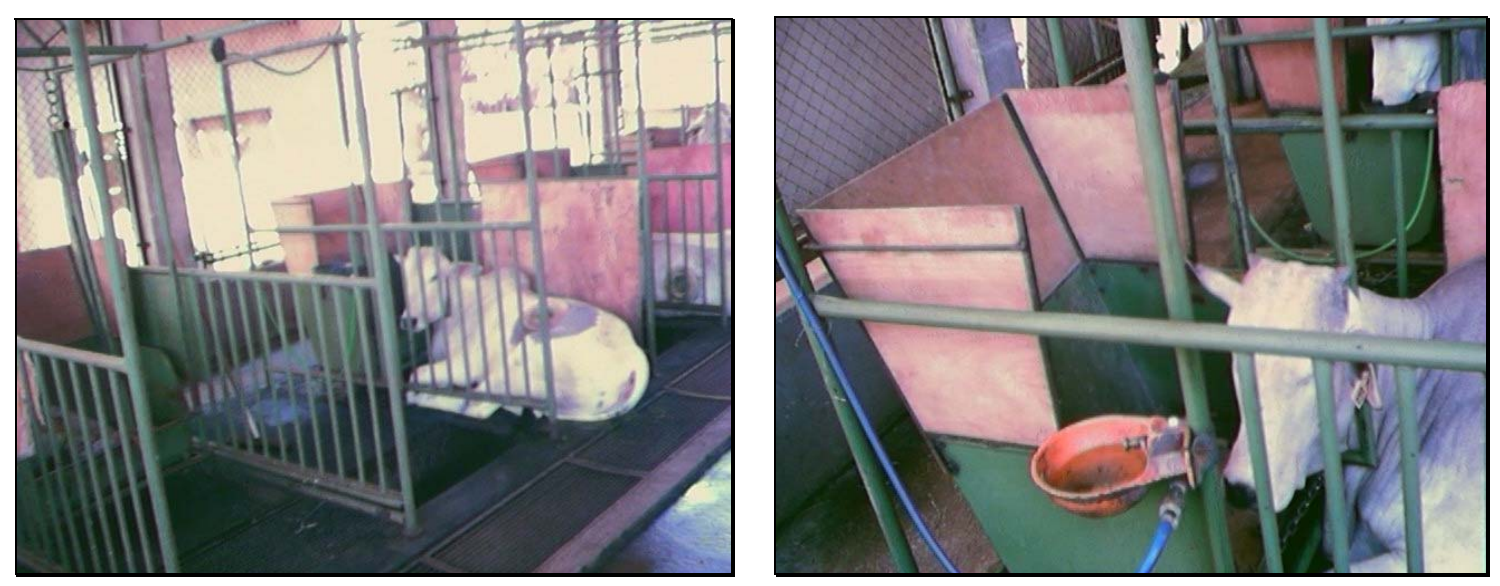

Figura 1 e 2 - Instalações dos animais

O período experimental total extendeu-se por aproximadamente 150 dias, entre os meses de dezembro de 2000 e maio de 2001. Sendo os primeiros 30 dias dedicados ao condicionamento dos animais às instalações experimentais, para que, então, pudessem ser realizados as cirurgias necessárias, os cuidados pós-operatórios e finalmente as coletas. Após o período de condicionamento, os animais foram submetidos às intervenções cirúrgicas para a colocação das cânulas de rúmen e duodeno, e receberam cuidados pós-operatórios, por cerca de 30 dias, até que os mesmos retomassem seu consumo normal. Depois de recuperados do processo cirúrgico iniciou-se o período experimental, que teve duração de 54 dias, divididos em quatro períodos de 14 dias, sendo, os nove 
primeiros para adaptação dos animais às dietas e os últimos cinco dias dedicados à coleta de amostras.

\subsection{Tratamentos}

Foram estabelecidos quatro tratamentos, utilizando-se duas fontes protéicas (farelo de soja $x$ uréia) e duas formas de processamento de milho (milho moído $\mathrm{x}$ milho floculado). Os tratamentos testados foram: 1) Milho moído + Uréia (MMU); 2) Milho moído + Farelo de Soja (MMFS); 3) Milho floculado + Uréia (MFU); 4) Milho floculado + Farelo de Soja (MFFS). Os quatro tratamentos tinham como volumoso feno de gramínea. A tabela 1 mostra a composição das dietas.

O procedimento utilizado para a obtenção do milho moído foi a trituração em um moinho de martelos, obtendo partículas com tamanho médio de $1,51 \mathrm{~mm}$. Já o milho floculado foi obtido através da exposição do grão ao vapor e à pressão atmosférica por trinta minutos, e posterior passagem por rolos auto-ajustáveis, operação esta realizada por uma empresa comercial. Obtiveram-se as densidades das duas formas de processamento de milho através da pesagem de um volume conhecido (proveta de um litro). O milho moído apresentou densidade de 639,9 
$\mathrm{g} /$ litro e o milho floculado $468,2 \mathrm{~g} /$ litro no momento do fornecimento das dietas. A densidade do milho floculado, obtida logo após a passagem pelos rolos, foi ao redor de $300 \mathrm{~g} / \mathrm{l}$, sendo este o procedimento de determinação da densidade usado como referência na maioria dos trabalhos de pesquisa. Para determinação do tamanho médio das partículas de milho, utilizou-se a técnica de peneiras descrita por Yu et al. (1998). Sendo os resultados apresentados na Tabela 2.

Tabela 1. Composição das dietas experimentais em \% da matéria seca

\begin{tabular}{lcccc}
\hline \multicolumn{5}{c}{ Composição das dietas experimentais } \\
\hline Ingredientes & MMFS & MMU & MFFS & MFU \\
\hline Feno de gramínea & 12,97 & 12,97 & 12,97 & 12,97 \\
Milho Moído & 75,36 & 83,14 & - & - \\
Milho Floculado & - & - & 75,36 & 83,14 \\
Uréia & - & 1,3 & - & 1,3 \\
Farelo de Soja & 9,08 & - & 9,08 & - \\
Minerais & 2,59 & 2,59 & 2,59 & 2,59 \\
Nutrientes & & & & \\
PB \% & 14,0 & 14,0 & 14,0 & 14,0 \\
NDT \% & 83,0 & 83,0 & 83,0 & 83,0 \\
FDN \% & 18,0 & 17,0 & 18,0 & 17,0 \\
\hline
\end{tabular}


Tabela 2. Tamanho de partículas do milho conforme o processamento

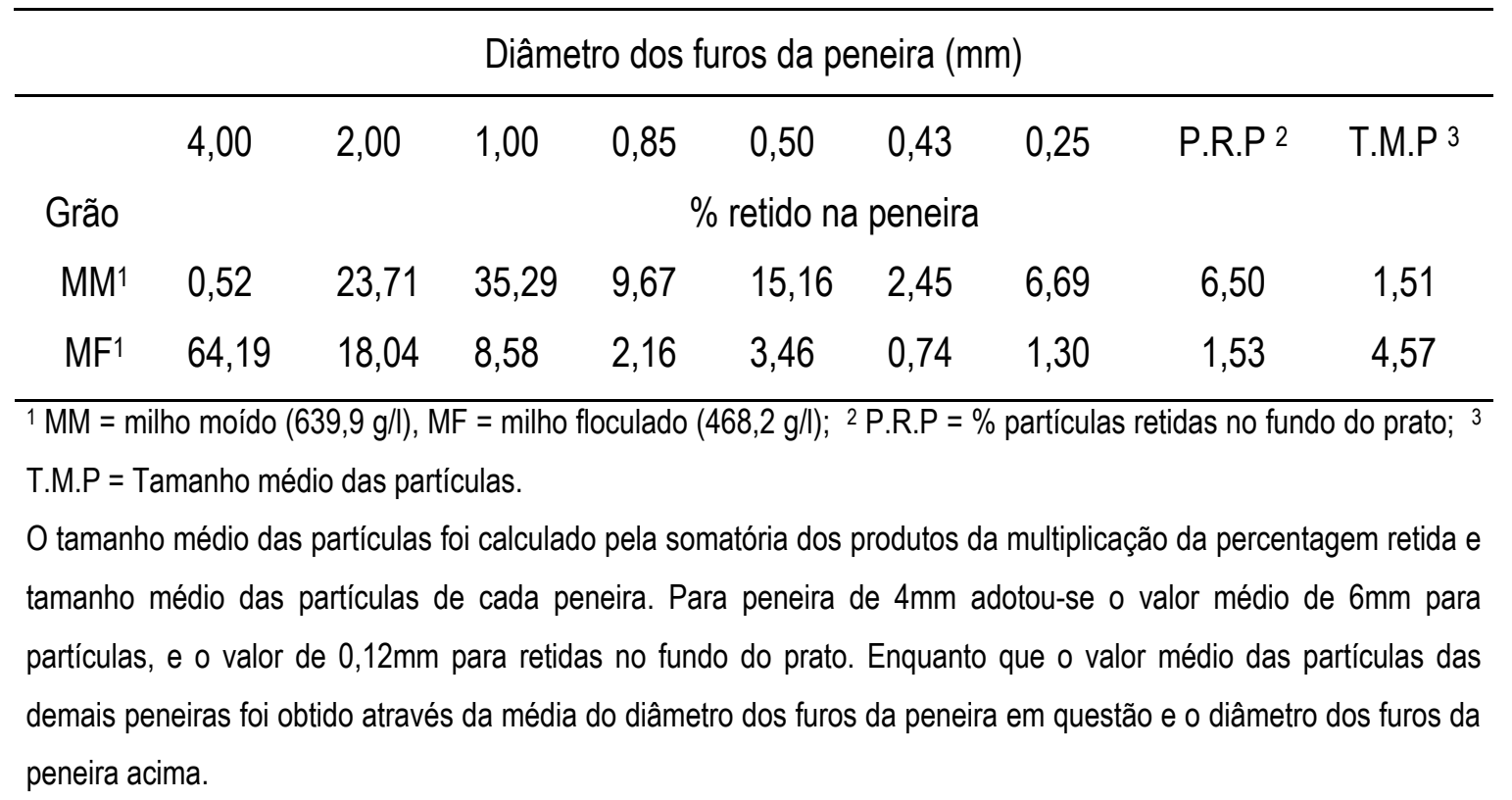

\subsection{Condução do experimento}

Após a cirurgia e a recuperação dos animais, o período experimental teve duração de 56 dias, divididos em 4 períodos de 14 dias cada. Os primeiros nove dias de cada período foram usados para adaptação dos animais aos tratamentos, e os cinco dias restantes para as coletas das amostras experimentais (conteúdo duodenal, fluido ruminal, sangue, fezes e ainda amostras dos alimentos oferecidos aos animais). 
Os animais foram arroçoados com ração completa uma vez ao dia (6:00h) ad libitum, permitindo sobra para evitar limitação de consumo por parte dos animais. No fornecimento da alimentação, eram pesadas as quantidades de volumoso e concentrado para posterior mistura no cocho, objetivando a obtenção da ração completa de cada animal. Durante os nove dias de adaptação, tanto o oferecido quanto as sobras foram pesados diariamente. Nos cinco dias do período de coleta, a quantidade oferecida da dieta foi fixa, utilizando-se o valor médio de consumo de cada animal durante os três últimos dias do período de adaptação. As sobras diárias, quando ocorridas no período de coleta, foram colocadas diretamente no rúmen de cada animal, para garantir o consumo pré-estabelecido. Os ingredientes da dieta foram amostrados diariamente, durante os cinco dias do período de coleta, compostos e armazenados à $-18^{\circ} \mathrm{C}$.

O cromo foi utilizado como marcador para a determinação da digestibilidade e fluxo dos nutrientes, tendo sido fornecido aos animais na forma de óxido de cromo $\left(\mathrm{Cr}_{2} \mathrm{O}_{3}\right)$ em dose diária de $40 \mathrm{~g} / \mathrm{animal}$. O $\mathrm{Cr}_{2} \mathrm{O}_{3}$ foi administrado logo após o fornecimento da dieta, via rúmen e envolto por guardanapo de papel (100\% fibras naturais) em dois envelopes de $20 \mathrm{~g}$ cada, os quais eram colocados na parte central do rúmen coberto pelo conteúdo ruminal, evitando-se desta forma que o marcador aderisse na parede do rúmen ou na cânula. 
Durante os primeiros quatro dias do período de coleta, foram tomadas amostras do bolo alimentar no duodeno $(300 \mathrm{ml})$ através da cânula duodenal e ainda amostras de fezes (200g) foram retiradas diretamente do reto dos animais. Ambas as coletas foram feitas as 6:00 e 14:00h no primeiro dia, as 8:00 e 16:00h no segundo dia, as 10:00 e 18:00h no terceiro dia e as 12:00 e 20:00h no quarto dia. Estes horários tiveram intervalo de oito horas, sempre adiantando 2 horas por dia, de modo a simular amostras obtidas a cada duas horas de um período de 14 horas seguintes ao fornecimento das dietas aos animais. As amostras foram compostas por animal dentro de cada período e armazenadas à $18{ }^{\circ} \mathrm{C}$ para posterior descongelamento e análise. No quinto dia do período de coleta, foi coletada uma amostragem extra do bolo alimentar no duodeno $(1000 \mathrm{ml})$, feita 4 horas após o fornecimento do alimento. $\mathrm{O}$ objetivo desta amostragem foi comparar os valores de cromo desta amostra com os das amostragens feitas duas vezes ao dia, como descrito anteriormente.

No segundo dia de cada período de coleta, quatro horas após o fornecimento das dietas, duas amostras do fluído ruminal de cada animal foram retiradas. A primeira amostra foi obtida através da filtragem do conteúdo ruminal em quatro camadas de tecido de algodão (fraldas), visando obter aproximadamente $100 \mathrm{ml}$ de fluido ruminal. Esta amostra teve $\mathrm{o} \mathrm{pH}$ determinado imediatamente com o potenciômetro 
digital da marca Digimed, modelo TE-902. Deste fluído foram retiradas duas alíquotas de $25 \mathrm{ml}$ cada, as quais foram acondicionadas em frasco plástico e congelada $\mathrm{a}-18{ }^{\circ} \mathrm{C}$. Uma segunda amostragem do conteúdo ruminal $(1000 \mathrm{ml})$ foi batida em liquidificador com $700 \mathrm{ml}$ de solução salina $(0,9 \% p v)$ por um minuto, filtrada também em quatro camadas de tecido de algodão (fraldas), e armazenando-se $500 \mathrm{ml}$ à $-18^{\circ} \mathrm{C}$.

No quinto dia do período de coleta, 4 horas após o fornecimento das dietas, amostras de sangue foram coletadas da jugular de cada animal, em tubos de ensaio com e sem anticoagulante. Os tubos sem anticoagulante ficaram fora da geladeira para que ocorresse a coagulação, enquanto que os tubos com anticoagulante foram acondicionados na geladeira até o dia seguinte, quando todas as amostras foram centrifugadas a 1500 RPM por 15 minutos a temperatura aproximada de $4{ }^{\circ} \mathrm{C}$ para extração de soro sanguíneo e de plasma,respectivamente, os quais foram acondicionados em ependorfes e congelados $\mathrm{a}-18^{\circ} \mathrm{C}$. 
3.4 Processamento e análises das amostras

3.4.1 Determinação de MS, MO, PB, amido, FDN e FDA

Para fins de análises laboratoriais as amostras dos ingredientes, das fezes e do conteúdo duodenal foram descongeladas, secas em estufas de ventilação forçada $\left(55^{\circ} \mathrm{C}\right)$ por 72 horas, moídas em moinho provido de peneira de $1 \mathrm{~mm}$ e analisadas para determinação de matéria seca (MS), matéria orgânica (MO) e proteína bruta (PB) de acordo com o AOAC (1990), amido pelo método descrito por Poore et al. (1993), fibra em detergente neutro (FDN) e fibra em detergente ácido (FDA) de acordo com os métodos propostos por Van Soest (1991) e adaptado para o aparelho ANKOM200 da Ankom Technology Corporation USA.

\subsubsection{Análises do fluido ruminal}

Após o descongelamento, as amostras de fluído ruminal $(25 \mathrm{ml})$ foram centrifugadas a $11.000 \mathrm{~g}$ com temperatura aproximada de $4{ }^{\circ} \mathrm{C}$ 
por 20 minutos. Uma alíquota de $4 \mathrm{ml}$ do sobrenadante foi transferida para um tubo de ensaio para posterior análise de $\mathrm{N}-\mathrm{NH} 3$ de acordo com o método colorimétrico descrito por Chaney e Marbach (1962) e adaptado para ser realizado em placas de microtítulo e posterior leitura em aparelho do tipo Elisa Reader (absorbância de 550 nanômetros). Uma segunda alíquota de $4 \mathrm{ml}$ foi utilizada para análise de AGVs de acordo com Anderson et al (1987) utilizando um cromatógrafo liquido gasoso (CLG) Hewlett Packard 5890, Series II (Hewlett-Packard Company, Avondale, PA) equipado com HP Integrador (Hewlett- Packard Company, Avondale, PA ). O padrão interno foi ácido 2-etilbutirico e o nitrogênio foi o gás de arraste. A temperatura do injetor, detector e coluna foram 150,190 e $115^{\circ} \mathrm{C}$, respectivamente.

3.4.3 Determinação da digestibilidade dos nutrientes

Amostras secas e moídas de duodeno e fezes também foram analisadas para cromo segundo Fenton \& Fenton (1979), para determinação da digestibilidade dos nutrientes.

A digestibilidade aparente da MS e demais nutrientes foi calculada da seguinte forma: 
Digestibilidade $=100-\left(100 \times \frac{\% \text { do marcador no alimento }}{\mathbf{x}} \%\right.$ do nutriente nas fezes $)$ do nutriente $(\%)$

$\%$ do marcador nas fezes $\%$ do nutriente no alimento

\subsubsection{Determinação de uréia plasmática}

As amostras de plasma sanguíneo foram analisadas para uréia plasmática de acordo com Chaney e Marbach (1962) adaptada para ser realizada em placas de microtítulo e posterior leitura em aparelho do tipo Elisa Reader BIO RAD (absorbância de 550 nanômetros).

\subsection{Delineamento e análise estatística}

O delineamento experimental utilizado foi um quadrado latino 4X4 (quatro animais $\mathrm{x}$ quatro períodos), tendo um arranjo fatorial do tipo $2 \times 2$, onde os fatores foram processamento de milho (moagem grosseira $x$ floculação) e fonte protéica (farelo de soja $x$ uréia). Adotando-se para análise estatística o procedimento GLM do programa 
estatístico SAS (1991). O quadro de análise de variância é mostrado na tabela 3.

Tabela 3. Quadro esquemático de análise de variância

\begin{tabular}{|c|c|}
\hline Causas de Variação & Graus de liberdade \\
\hline Animal & 3 \\
\hline Período & 3 \\
\hline Tipo de processamento do grão & 1 \\
\hline Fonte proteica & 1 \\
\hline Tipo de processamento $x$ fonte proteica & 1 \\
\hline Resíduo & 6 \\
\hline TOTAL & 15 \\
\hline
\end{tabular}

As diferenças entre os tratamentos para as diversas variáveis avaliadas foram verificadas através do teste de Tukey, considerando $5 \%$ $(P<0,05)$ como nível de significância. 


\section{RESULTADOS}

\subsection{Composição dos alimentos utilizados}

A composição das dietas e os valores encontrados na análise bromatológica dos ingredientes utilizados estão apresentados nas Tabelas 4 e 5 , respectivamente.

Tabela 4. Composição das dietas em \% da MS

\begin{tabular}{lcccc}
\hline & \multicolumn{3}{c}{ Dietas } \\
\cline { 2 - 5 } Nutrientes $^{1}$ & MMFS & MMU & MFFS & MFU \\
\hline MO & 83,66 & 82,92 & 83,72 & 82,99 \\
PB & 13,14 & 12,83 & 12,98 & 12,65 \\
Amido & 58,68 & 64,12 & 63,78 & 69,73 \\
FDN & 19,20 & 18,95 & 15,82 & 15,23 \\
FDA & 6,98 & 6,47 & 6,62 & 6,07 \\
\hline
\end{tabular}

${ }^{1}$ Nutrientes: $\mathrm{MO}=$ matéria orgânica; $\mathrm{PB}=$ proteína bruta; FDN = fibra em detergente neutro; FDA = fibra em detergente ácido. 
Tabela 5. Composição química dos alimentos

\begin{tabular}{lcccccc}
\hline Fração $^{1}$ & Unidade & MF2 $^{2}$ & MM $^{3}$ & F. Soja & Uréia & Feno $^{5}$ \\
\hline MS & $\%$ & 87,97 & 88,35 & 88,06 & 99,00 & 89,78 \\
MO & $\%$ MS & 87,11 & 87,03 & 82,13 & - & 81,48 \\
PB & $\%$ MS & 8,96 & 9,18 & 51,26 & 281 & 12,00 \\
Amido & $\%$ MS & 83,63 & 76,88 & 5,67 & - & 1,58 \\
FDN & $\%$ MS & 9,16 & 13,64 & 14,29 & - & 65,41 \\
FDA & $\%$ MS & 1,80 & 2,28 & 7,53 & - & 35,27 \\
EE & $\%$ MS & 2,58 & 2,76 & 1,98 & - & 1,59 \\
\hline
\end{tabular}

1 Fração: $\mathrm{MS}$ = matéria seca; $\mathrm{MO}$ = matéria orgânica; $\mathrm{PB}=$ proteína bruta; FDN = fibra em detergente neutro; $\mathrm{FDA}=$ fibra em detergente ácido; $\mathrm{EE}=$ Extrato Etéreo. ${ }^{2} \mathrm{MF}=$ Milho floculado; ${ }^{3} \mathrm{MM}=$ Milho moído; ${ }^{4}$ F Soja $=$ Farelo de soja; ${ }^{5}$ Feno $=$ Feno de gramínea .

\subsubsection{Milho floculado e milho moído}

Os teores de proteína bruta do milho floculado (8,96\%) e do milho moído (9,18\%), foram próximos aos valores do N.R.C (1996) (910\%), e dos 8,7\% apresentado por Brown et al (2000).

Os teores de amido do milho floculado (83,63\%) e milho moído (76,88\%), estão acima das médias de $72 \%$ citada por Huntington (1997) e Joy et al (1997); 71,1\% citada por Zinn (1991); 66,1\% citada por Brown et 
al (2000); e 64\% citada por Plascencia e Zinn (1996), mas o milho moído está dentro da média de $76,1 \pm 8 \%$ citada por Patton (1994). Essas diferenças podem ser explicadas em parte, pelas diferentes procedências dos milhos, já que o floculado é oriundo de uma empresa mineira, enquanto que o moído foi processado na fabrica de ração pertencente ao Departamento de Produção Animal da ESALQ/USP. Deste modo, a procedência provavelmente poderá traduzir efeitos como genótipo do híbrido e processamento na colheita e pós-colheita, entre outros. Outro aspecto a ser considerado, é que durante a floculação, parte da hemicelulose componente da fração FDN do milho, pode ter sido solubiizada, resultando em glucose livre a qual pode ter sido lida pelo equipamento e interpretada com sendo proveniente da digestão enzimática do amido. O menor teor de FDN do milho floculado $(9,16 \%)$ em relação ao moído fino $(13,64)$, sugere que esta hipótese pode ter se concretizado.

\subsubsection{Farelo de soja}

Os dados de composição do farelo de soja, como proteína bruta (51,26\%), amido (5,67\%), FDN (14,29\%) e FDA (7,53\%) estão próximos 
aos valores da tabela do NRC (1996) e indicam que o produto era de boa qualidade.

4.1.3 Feno de gramínea

Os teores de proteína bruta (12\%), FDN $(64,51 \%)$ e FDA $(35,27)$, indicam que o feno utilizado era de boa qualidade.

4.2 Parâmetros avaliados

4.2.1 Parâmetros ruminais e sanguíneo

Os efeitos dos tratamentos sobre os parâmetros sanguíneos e ruminais estão apresentados na Tabela 6 e Figura 1, enquanto que os valores de PB, Amido, FDN e FDA encontrados nas amostras do bolo alimentar do duodeno e nas fezes estão apresentados nas tabelas 7 e 8 respectivamente, assim como nas Figuras 2 e 3. 
Como pode ser observado na Tabela 6, a floculação do milho reduziu $(P<0,05)$ a concentração de uréia plasmática $(12,18$ e 11,60 $\mathrm{mg} / \mathrm{dl})$ em comparação com a moagem fina $(17,84$ e $16,33 \mathrm{mg} / \mathrm{dl})$. No entanto, a concentração de uréia plasmática não foi afetada ( $P>0,05)$ pela substituição de uma fonte de proteína verdadeira como o farelo de soja $(17,84$ e $12,18 \mathrm{mg} / \mathrm{dl})$ por uma fonte de NNP como a uréia $(16,33$ e 11,60 $\mathrm{mg} / \mathrm{dl})$. Também não houve $(P>0,05)$ interação entre processamento e fonte protéica.

Tabela 6. Efeito dos tratamentos sobre os parâmetros avaliados no fluido ruminal e sangue

\begin{tabular}{|c|c|c|c|c|c|c|c|}
\hline \multirow[b]{2}{*}{ Parâmetros ${ }^{1}$} & \multicolumn{4}{|c|}{ Tratamentos } & \multicolumn{3}{|c|}{ Efeito $(\mathrm{P}<)^{2}$} \\
\hline & MMFS & MMU & MFFS & MFU & PM & FP & $\mathrm{PM} \times \mathrm{FP}$ \\
\hline UP (mg.dl-1) & 17,84 & 16,33 & 12,18 & 11,60 & 0.0178 & 0.5395 & 0.7800 \\
\hline $\mathrm{N}-\mathrm{NH}_{3}\left(\mathrm{mg} \cdot \mathrm{dl}^{-1}\right)$ & 19,08 & 26,20 & 4,69 & 4,90 & 0.0003 & 0.1860 & 0.2094 \\
\hline $\mathrm{Ph}$ & 6,34 & 6,31 & 5,93 & 5,88 & 0.1475 & 0.8686 & 0.9736 \\
\hline $\mathrm{C}_{2}(\mathrm{mM})$ & 59,5 & 56,1 & 56,7 & 59,5 & 0.9655 & 0.9631 & 0.6745 \\
\hline $\mathrm{C}_{3}(\mathrm{mM})$ & 22,5 & 23,1 & 35,3 & 33,4 & 0.0069 & 0.8351 & 0.6843 \\
\hline $\mathrm{C}_{4}(\mathrm{mM})$ & 9,5 & 13,6 & 11,1 & 8,7 & 0.4827 & 0.7334 & 0.1995 \\
\hline $\mathrm{C}_{2} / \mathrm{C}_{3}$ & 2,8 & 2,5 & 1,7 & 2,1 & 0.0134 & 0.4664 & 0.4664 \\
\hline
\end{tabular}




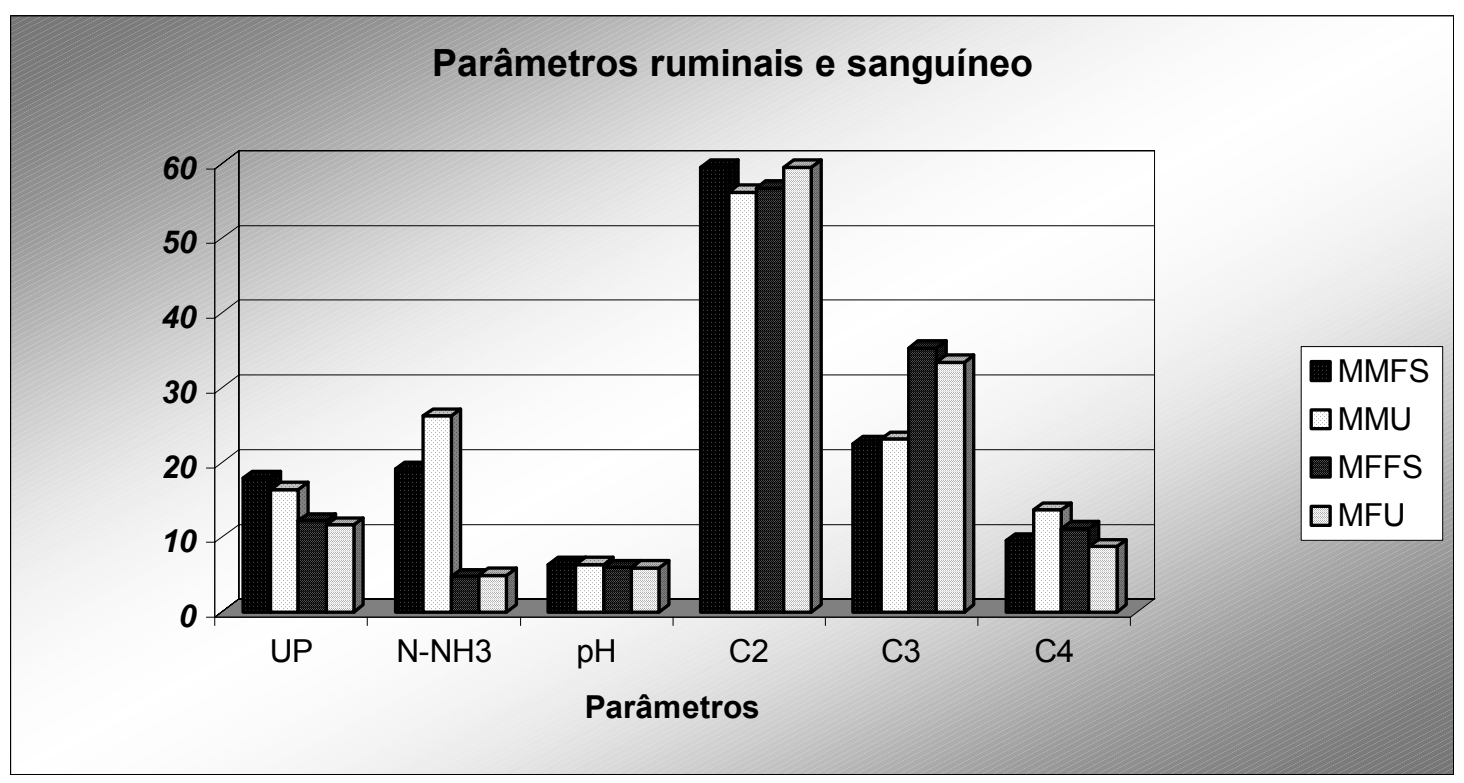

Figura 3 - Parâmetros ruminais e sanguíneo

A floculação do milho também foi efetiva em reduzir $(P<0,01)$ a concentração ruminal de $\mathrm{N}-\mathrm{NH}_{3}(4,69$ e $4,90 \mathrm{mg} / \mathrm{dl})$, em comparação com a moagem fina do milho (19,08 e $26,20 \mathrm{mg} / \mathrm{dl})$. No entanto, assim como para uréia plasmática, a concentração ruminal de $\mathrm{N}-\mathrm{NH}_{3}$ não foi afetada $(P>0,05)$ pela substituição de uma fonte de proteína verdadeira como o farelo de soja $(19,08$ e 4,69 mg/dl) por uma fonte de NNP como a uréia $(26,20$ e $4,90 \mathrm{mg} / \mathrm{dl})$. Também não houve $(P>0,05)$ interação entre processamento e fonte protéica.

Houve uma leve tendência $(P<0,15)$ de redução do $\mathrm{pH}$ ruminal quando o milho foi floculado $(5,93$ e 5,88$)$ em comparação com o milho 
moído fino $(6,34$ e 6,31$)$. Não houve interação $(P>0,05)$ entre os fatores analisados.

As concentrações molares de $C_{2}$ e $C_{4}$ no fluido ruminal não foram afetadas $(P>0,05)$ pelas fontes de amido nem pelas fontes protéicas. Entretanto, a floculação aumentou significativamente $(P<0,01)$ as concentrações molares de $C_{3}(35,3$ e 33,4 mM) em comparação com a moagem fina do milho $(22,5$ e $23,1 \mathrm{mM})$. Devido a estes fatos, a relação $C_{2} / C_{3}$ foi menor $(P<0,05)$ no fluido ruminal de novilhos recebendo milho floculado.

\subsubsection{Parâmetros duodenais}

Os dados de digestão ruminal foram comprometidos pela baixa recuperação do cromo no bolo alimentar do duodeno, resultando em valores muitas vezes negativos, conforme mostrado na Figura 4 e na Tabela 7. 


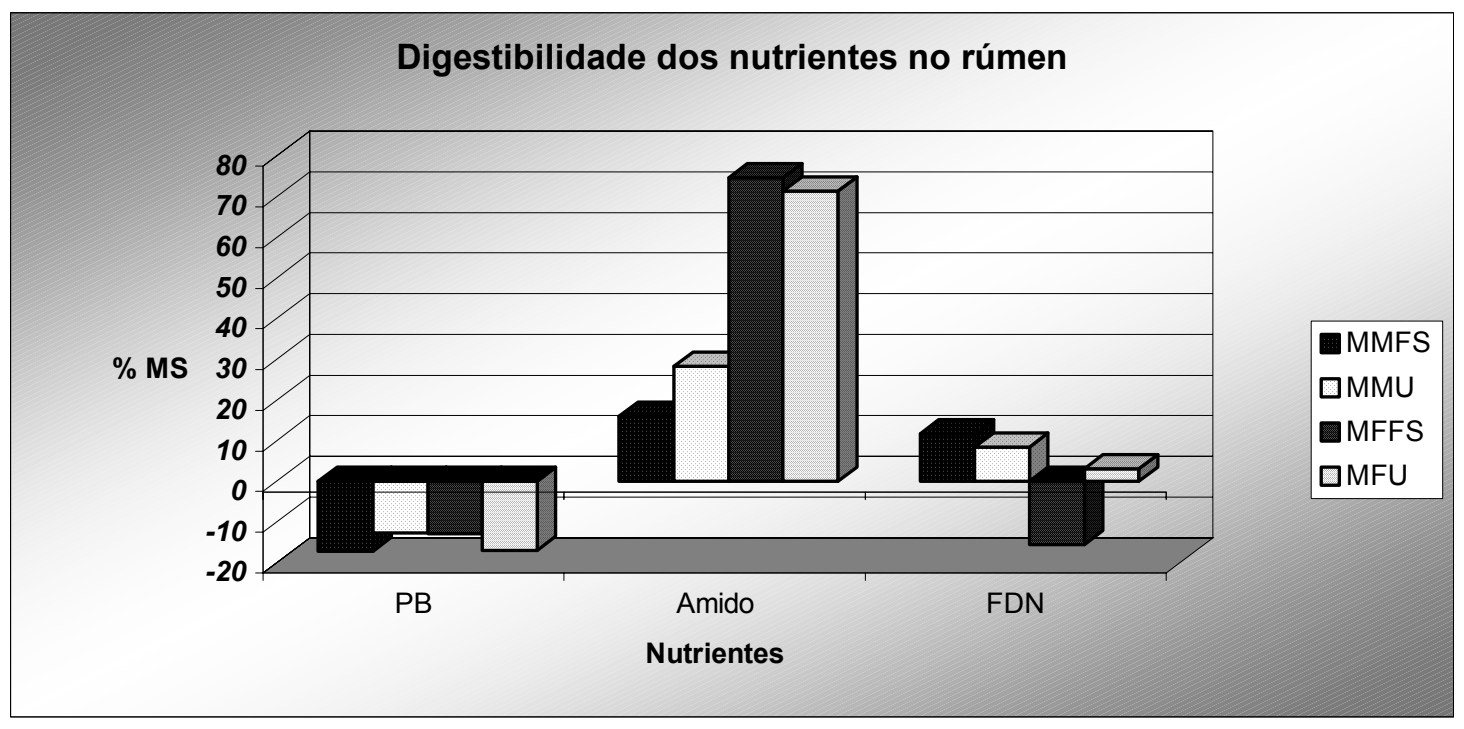

Figura 4 - Digestibilidade dos nutrientes no rúmen

Tabela 7. Efeito dos tratamentos sobre a digestibilidade ruminal dos nutrientes

\begin{tabular}{lccccccc}
\hline & \multicolumn{4}{c}{ Tratamentos } & \multicolumn{3}{c}{ Efeito $(\mathrm{P}<)^{2}$} \\
\cline { 2 - 8 } Parâmetros $^{1}$ & MMFS & MMU & MFFS & MFU & PM & FP & PM x FP \\
\hline PB & $-17,18$ & $-12,80$ & $-12,93$ & $-17,14$ & 0.9948 & 0.9908 & 0.5409 \\
A & 15,95 & 28,18 & 74,64 & 71,30 & 0.0001 & 0.2127 & 0.0503 \\
FDN & 11,59 & 8,45 & $-15,57$ & 2,93 & 0.0022 & 0.8151 & 0.3061 \\
\hline${ }^{1}$ PB = Proteína bruta; A = Amido; FDN = Fibra em detergente neutro; ${ }^{2}$ PM = Processamento do milho; FP = Fonte \\
protéica; PM x FP = Interação.
\end{tabular}


Os dados de concentração de nutrientes no bolo alimentar são apresentados na Tabela 8.

Tabela 8. Efeito dos tratamentos sobre as concentrações de nutrientes no bolo alimentar no duodeno (\% da MS)

\begin{tabular}{lccccccc}
\hline & \multicolumn{3}{c}{ Tratamentos } & \multicolumn{3}{c}{ Efeito $(\mathrm{P}<)^{2}$} \\
\cline { 2 - 8 } Parâmetros1 $^{2}$ & MMFS & MMU & MFFS & MFU & PM & FP & PM x FP \\
\hline PB & 16,0 & 15,9 & 22,9 & 22,9 & 0.0018 & 0.9781 & 0.9635 \\
A & 51,4 & 50,6 & 25,2 & 30,9 & 0.0007 & 0.5192 & 0.4028 \\
FDN & 17,7 & 19,1 & 28,5 & 22,8 & 0.0005 & 0.0953 & 0.0169 \\
FDA & 8,5 & 7,8 & 16,1 & 11,5 & 0.0114 & 0.1422 & 0.2643 \\
\hline 1 PB = Proteína bruta; A = Amido; FDN = Fibra em detergente neutro; FDA = Fibra em detergente ácido. \\
2 PM = Processamento do milho; FP = Fonte protéica; PM x FP = Interação.
\end{tabular}

Os valores apresentados na Tabela 8, mostram que a floculação do milho, aumentou significativamente $(P<0,01)$ as concentrações de proteína bruta e de FDN e de FDA no bolo alimentar do duodeno e diminuiu $(P<0,01)$ as concentrações de amido em comparação com a moagem fina.

As fontes protéicas não afetaram $(P>0,05)$ as concentrações de nutrientes no bolo alimentar do duodeno. 


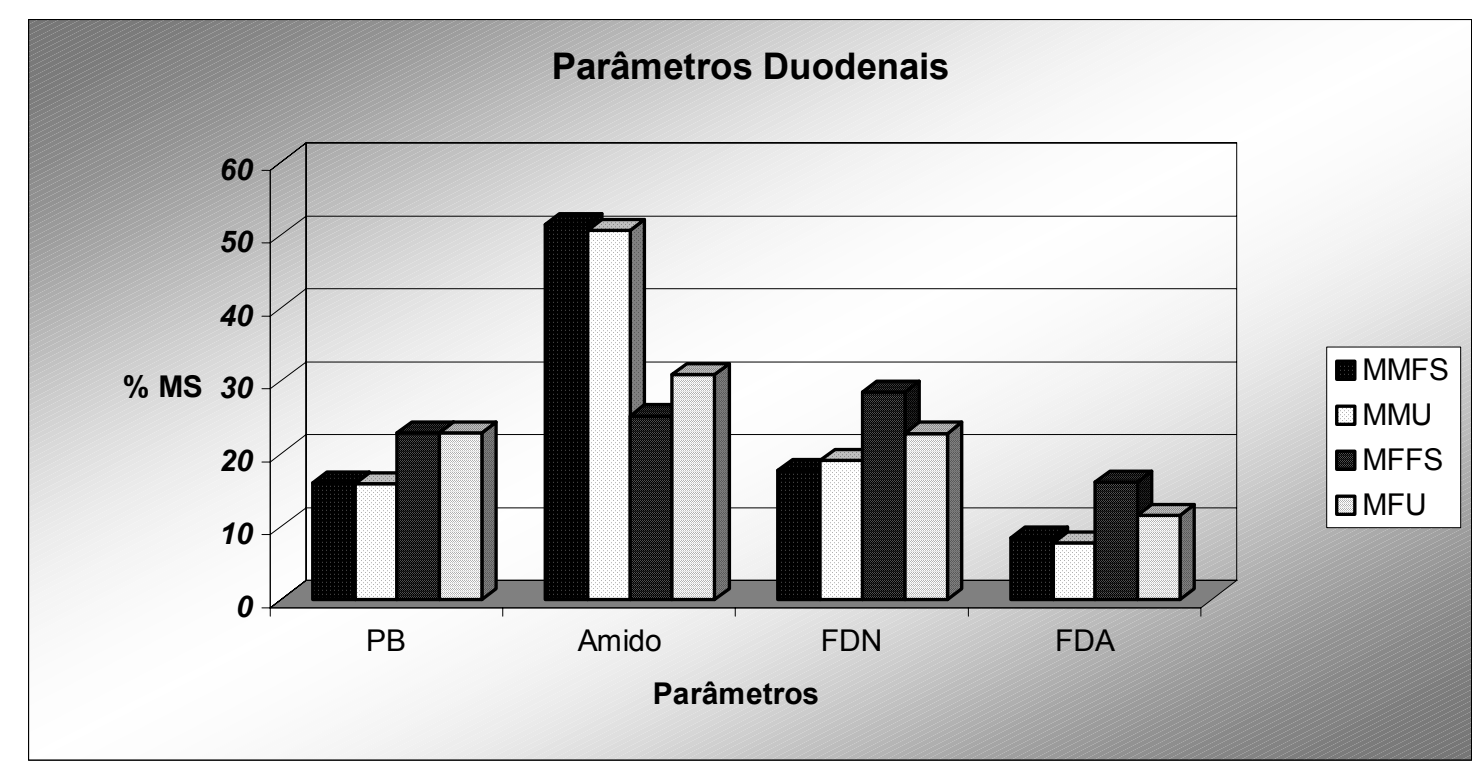

Figura 5 - Parâmetros duodenais

\subsubsection{Parâmetros fecais}

Os dados da Tabela 9 mostram que a floculação do milho reduziu $(P<0,01)$ as concentrações fecais de amido, e aumentou $(P<0,05)$ as de PB, FDN e FDA em comparação com o milho moído fino.

As fontes protéicas não afetaram $(P>0,05)$ as concentrações fecais de amido, PB, FDN e FDA. 
Tabela 9. Efeito dos tratamentos sobre os parâmetros avaliados nas fezes em \% da MS

\begin{tabular}{lccccccc}
\hline & \multicolumn{3}{c}{ Tratamentos } & \multicolumn{3}{c}{ Efeito $(P<)^{2}$} \\
\cline { 2 - 7 } Parâmetros $^{1}$ & MMFS & MMU & MFFS & MFU & PM & FP & PM x FP \\
\hline PB & 12,1 & 12,2 & 16,1 & 15,5 & 0.0381 & 0.8584 & 0.7934 \\
A & 25,0 & 24,4 & 3,3 & 2,8 & 0.0013 & 0.8999 & 0.9863 \\
FDN & 41,1 & 37,3 & 52,5 & 50,6 & 0.0117 & 0.4340 & 0.7909 \\
FDA & 19,3 & 18,4 & 25,1 & 25,2 & 0.0037 & 0.7773 & 0.7219 \\
\hline 1 PB = Proteína bruta; A = Amido; FDN = Fibra em detergente neutro; FDA = Fibra em detergente ácido. \\
2 PM = Processamento do milho; FP = Fonte protéica; PM x FP = Interação.
\end{tabular}

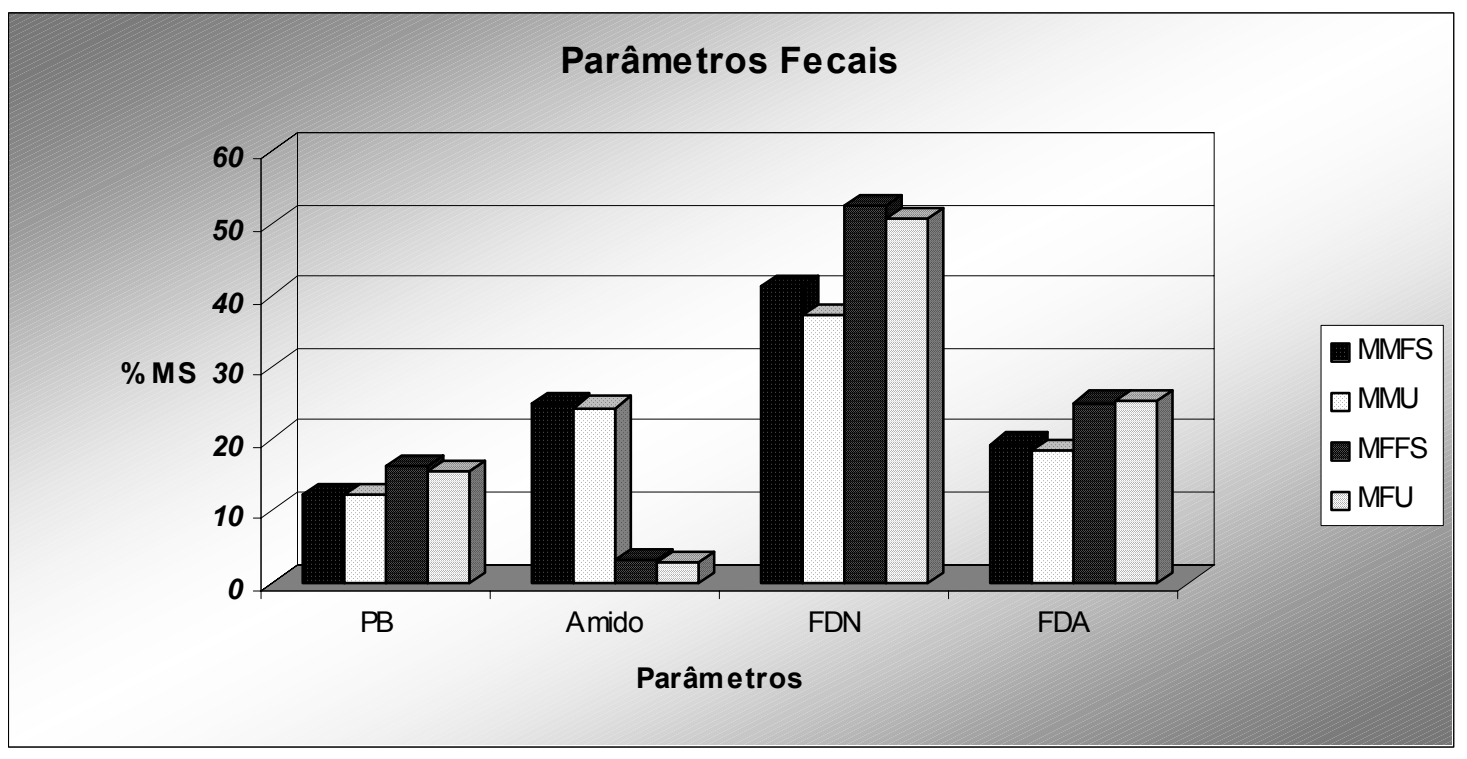

Figura 6 - Parâmetros fecais 


\subsection{Consumo de matéria seca e digestibilidade dos nutrientes}

O consumo diário e digestibilidade aparente da matéria seca no trato total estão apresentados na Tabela 10. Não houve efeito $(P>0,05)$ do processamento de grãos e de fonte protéica no consumo diário e na digestibilidade da matéria seca no trato total, apesar de haver um menor valor numérico de CMS para as dietas com milho moído fino.

Tabela 10. Efeitos dos tratamentos sobre o consumo e digestibilidade de MS

\begin{tabular}{lccccccc}
\hline & \multicolumn{4}{c}{ Tratamentos } & \multicolumn{3}{c}{ Efeito $(\mathrm{P}<)^{3}$} \\
\cline { 2 - 8 } Item & MMFS & MMU & MFFS & MFU & PM & FP & PM x FP \\
\hline CMS $\left(\text { Kg.d }^{-1}\right)^{1}$ & 5,1 & 4,6 & 6,0 & 5,4 & 0.1857 & 0.3407 & 0.9122 \\
DMSTT (\%) ${ }^{2}$ & 74,7 & 68,4 & 71,8 & 72,9 & 0.8529 & 0.5757 & 0.4303 \\
\hline 1 Consumo de Matéria Seca; $^{2}$ Digestibilidade da Matéria Seca no Trato total; ${ }^{3}$. PM $=$ Processamento do milho, \\
FP = Fonte protéica; Interação.
\end{tabular}

O consumo diário e a digestibilidade aparente dos nutrientes no trato total estão apresentados na Tabela 11 e Figura 7.

Houve uma leve tendência $(P<0,14)$ de um maior consumo de $P B$ nas dietas com milho floculado $(0,78 \mathrm{~kg}$ e $0,68 \mathrm{~kg})$ em comparação às 
dietas com milho moído fino $(0,67 \mathrm{~kg}$ e $0,59 \mathrm{~kg})$, ao passo que a digestibilidade da PB foi tendeu a ser menor $(P<0,1)$ nas dietas contendo milho floculado $(65,07$ e $66,89 \%)$ em comparação com o moído fino $(76,73$ e $69,95 \%)$

Tabela 11. Efeitos dos tratamentos sobre a digestibilidade aparente dos nutrientes no trato total

\begin{tabular}{|c|c|c|c|c|c|c|c|}
\hline \multirow[b]{2}{*}{ Item $^{1}$} & \multicolumn{4}{|c|}{ Tratamentos } & \multicolumn{3}{|c|}{ Efeito $(P<)^{2}$} \\
\hline & MMFS & MMU & MFFS & MFU & PM & $\mathrm{FP}$ & $\mathrm{PM} \times \mathrm{FP}$ \\
\hline CPB $\left(\mathrm{Kg} \cdot \mathrm{d}^{-1}\right)$ & 0,67 & 0,59 & 0,78 & 0,68 & 0.1379 & 0.3785 & 0.8555 \\
\hline DPBTT $\left(K_{g} \cdot d^{-1}\right)$ & 0,51 & 0,41 & 0,51 & 0,46 & 0.9194 & 0.1768 & 0.6166 \\
\hline DPBTT (\%) & 76,73 & 69,95 & 65,07 & 66,89 & 0.0651 & 0.4772 & 0.2358 \\
\hline $\mathrm{CA}\left(\mathrm{Kg} \mathrm{d}^{-1}\right)$ & 3,01 & 2,97 & 3,83 & 3,75 & 0.0584 & 0.8664 & 0.9608 \\
\hline $\operatorname{DATT}\left(\mathrm{Kg} \mathrm{d}^{-1}\right)$ & 2,69 & 2,61 & 3,77 & 3,71 & 0.0156 & 0.8218 & 0.9593 \\
\hline DATT (\%) & 89,22 & 87,96 & 98,56 & 98,90 & 0.0017 & 0.8162 & 0.6875 \\
\hline CFDN $\left(\mathrm{Kg} \cdot \mathrm{d}^{-1}\right)$ & 0,98 & 0,88 & 0,95 & 0,82 & 0.6199 & 0.2413 & 0.9079 \\
\hline DFDNTT $\left(K g . d^{-1}\right)$ & 0,45 & 0,33 & 0,09 & 0,12 & 0.0042 & 0.5498 & 0.2590 \\
\hline DFDNTT (\%) & 45,81 & 37,85 & 9,52 & 14,63 & 0.0022 & 0.8151 & 0.3061 \\
\hline
\end{tabular}




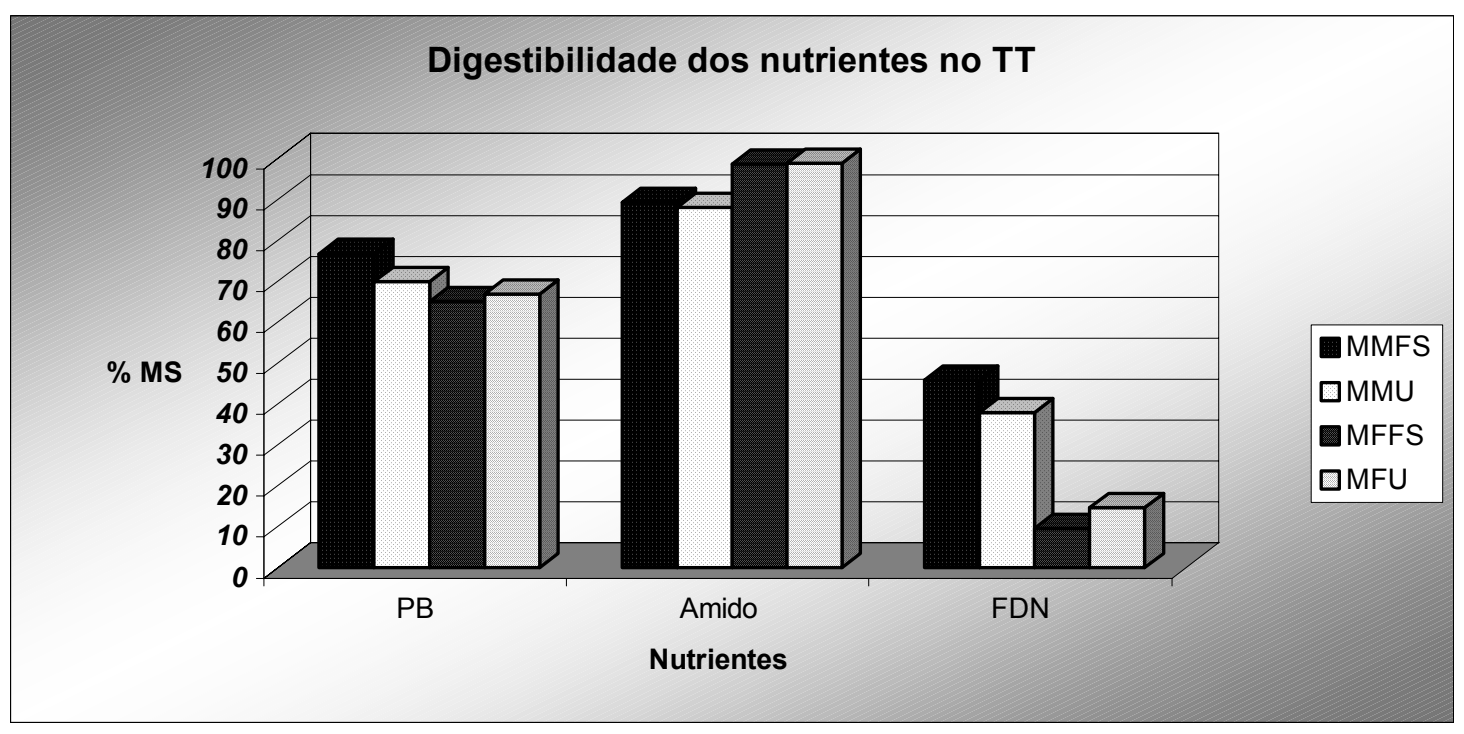

Figura 7 - Digestibilidade dos nutrientes no trato total

O consumo de amido tendeu $(P<0,1)$ a ser maior nas dietas com milho floculado $(3,83 \mathrm{Kg}$ e $3,75 \mathrm{Kg})$ em comparação às dietas com milho moído fino $(3,01 \mathrm{Kg}$ e $2,97 \mathrm{Kg})$, assim como a digestibilidade do amido no trato total, que foi dez unidades percentuais maior $(\mathrm{P}<0,01)$ para as dietas com milho floculado $(98,56 \%$ e $98,90 \%)$ em comparação às dietas com milho moído fino $(89,22 \%$ e $87,96 \%)$.

Os tratamentos não afetaram $(P>0,05)$ o consumo de FDN, entretanto, a digestibilidade do FDN no trato total, foi expressivamente deprimida $(P<0,01)$ nas dietas com milho floculado $(9,52 \% 14,63 \%)$ em comparação com milho moído fino $(45,81 \%$ e $37,85 \%)$. 
Tanto o consumo como a digestibilidade no trato total da MS, da PB, do amido e da FDN, não foram afetadas pelas fontes protéicas testadas $(P>0,05)$.

\subsection{Fluxo de proteína microbiana}

O fluxo de proteína microbiana não foi possível de ser determinado, pois o óxido de cromo, utilizado para estimar a digestibilidade ruminal aparente da matéria seca, apresentou valores consistentes de recuperação no bolo alimentar do duodeno, apenas nas dietas contendo milho floculado. Diversos valores negativos de digestibilidade foram observados nas dietas com milho moído fino, conforme mostrado na Tabela 12. 
Tabela 12. Digestibilidade ruminal das dietas em $\%$ da MS ingerida

\begin{tabular}{ccccc}
\hline & \multicolumn{3}{c}{ Tratamentos } \\
Período & MMFS & MMU & MFFS & MFU \\
\hline 1 & $-2,01$ & $-10,90$ & 32,51 & 39,40 \\
2 & 20,66 & 31,93 & 23,80 & 42,57 \\
3 & $-11,68$ & 7,96 & 64,47 & 14,19 \\
4 & 9,15 & 7,21 & 22,69 & 44,97 \\
\hline
\end{tabular}

\subsection{Aminoácidos totais}

Devido à impossibilidade de se calcular o fluxo de matéria seca para o duodeno, o fluxo de aminoácidos também não pode ser determinado. 


\section{DISCUSSÃO}

\subsection{Composição das dietas}

As dietas testadas neste estudo foram formuladas de acordo com o NRC (1996), visando um alto ganho de peso dos animais. Dietas, comumente utilizadas nos confinamentos brasileiros, caracterizam-se por conterem uma menor participação do alimento concentrado que a utilizada neste estudo ( $88 \%$ ), entretanto, tem se observado uma tendência de aumento na utilização de dietas com alta densidade energética em nossos confinamentos nos últimos anos. Isto pode ser explicado pela profissionalização da atividade nos confinamentos de maior porte, pela elevação no custo de produção de silagens e conseqüente redução no diferencial de custo da energia proveniente de grãos de cereais $x$ forragem. Soma-se a este fato, a maior oferta de novilhos com bom potencial genético para ganhos elevados, 
especialmente, os resultantes de cruzamento industrial, entre zebuínos e taurinos.

Em um levantamento conduzido por Galyean (1996), entrevistando nutricionistas responsáveis por diversos confinamentos americanos, com um universo de 3,6 milhões de bovinos/ano, mostrou que as dietas de terminação utilizadas são semelhantes as deste estudo, com alto teor de concentrado (89 a 97\%), fontes de amido com alta degradabilidade ruminal (milho ou sorgo floculado ou silagem de grão úmido) com 12,5 a $14,4 \%$ de $\mathrm{PB}$, fazendo uso de uréia na dieta $(0,5$ a 1,5\%) e não utilizando fontes protéicas ricas em PNDR. O autor enfatizou que o desempenho animal tem sido superior com dietas com teores de PB mais elevados que o recomendado pelo sistema fatorial adotado pelo NRC (1984) e que as recomendações feitas utilizando os novos sistemas de proteína metabolizável (NRC, 1996) são mais consistentes com o que vem sendo adotado pelos confinamentos comerciais atualmente nos Estados Unidos. A mesma revisão também permitiu concluir que uma melhora no desempenho de bovinos em terminação, recebendo dietas com alto teor de concentrado, tem sido mais consistente quando a proteína suplementar é proveniente de fontes de alta degradabilidade em comparação com fontes de baixa degradabilidade ruminal. 


\subsubsection{Parâmetros ruminais e sanguíneos}

Apesar da baixa recuperação do cromo, os dados de concentração de amido no bolo alimentar do duodeno foram significativamente inferiores para bovinos recebendo dietas com milho floculado, em comparação com o moído fino, assim como as expressivas reduções nas concentrações de $\mathrm{N}-\mathrm{NH}_{3}$ no rúmen e de uréia plasmática, aumento das concentrações molares de $C_{3}$, aliadas à uma tendência de menor pH ruminal, indicam que a floculação foi efetiva em aumentar a degradabilidade ruminal do amido do milho. Inúmeros relatos na literatura têm comprovado este fato (Huntington, 1997; Theurer et al., 1999). Incrementos variáveis, da ordem de 10 a mais de 20 unidades percentuais na degradabilidade ruminal do amido, têm sido relatados por esses autores para o milho ou sorgo floculados, em comparação com grãos laminados ou moídos grosseiramente. Dados de degradabilidade ruminal do milho moído fino, infelizmente são escassos na literatura, e esta informação seria de grande valia na formulação de dietas no Brasil, uma vez que a moagem é a forma mais comum de processamento destes grãos no Brasil.

A maior disponibilidade de energia fermentável no rúmen de bovinos recebendo fontes ricas em amido degradável estimula a síntese 
microbiana (Poore et al., 1992; Oliveira et al., 1992; Zinn et al., 1990; Plascencia \& Zinn, 1996), o que explica a menor concentração de $\mathrm{N}-\mathrm{NH}_{3}$ no fluido ruminal, observada neste estudo nos novilhos recebendo milho floculado $(4,69 \mathrm{mg} / \mathrm{dl}$ e $4,90 \mathrm{mg} / \mathrm{dl})$ comparado ao moído fino $(19,08 \mathrm{mg} / \mathrm{dl}$ e $26,20 \mathrm{mg} / \mathrm{dl})$. Zinn et al. (1995) comparando dietas com milho moído e floculado, também encontraram valores de $\mathrm{N}-\mathrm{NH}_{3}$ ruminal inferiores para o milho floculado. Beauchemin et al. (2001) estudando efeitos do processamento dos grãos de cevada (amido com alta degradabilidade ruminal) na digestão de dietas de terminação com $13,9 \%$ PB e $45,7 \%$ de amido, encontraram valores médios de $\mathrm{N}-\mathrm{NH}_{3}$ ao redor de $11,8 \mathrm{mg} / \mathrm{dl}$, valores estes superiores aos observados neste estudo com milho floculado, mas inferiores aos observados com milho moído fino. Os valores de $\mathrm{N}-\mathrm{NH}_{3}$ ruminal nos tratamentos com milho moído foram muito maiores que os descritos por Shain et al. (1998) (1,65 - 7,89mg/dl) em dietas com milho moído e níveis crescentes de uréia. Vale frisar que os valores observados em nosso estudo foram obtidos em coletas de fluido ruminal feitas 4 horas após a alimentação e não a valores médios diários.

Segundo Taniguchi et al. (1995) e Huntington et al. (1996), a degradabilidade ruminal do amido afeta a quantidade de amônia disponível para absorção, e a absorção de amônia tem relação direta com a síntese de uréia no fígado. De acordo com Alio et al. (2000), os 
ruminantes absorvem uma boa quantidade de nitrogênio como amônia através da parede ruminal, a qual é totalmente removida do sangue pelo fígado e sintetizada em uréia, para ser reciclada de volta ao rúmen ou excretada via urina. Grãos floculados, comparados a grãos moídos, aumentaram proporcionalmente a fermentação do amido no rúmen (Theurer, 1996; Huntington, 1997), o fluxo de proteína microbiana para o duodeno (Zinn et al., 1990), e a eficiência do ganho de peso por novilhos em crescimento (Barajas \& Zinn, 1998).

A menor perda de amônia para a corrente sanguínea e a maior reciclagem de uréia para o rúmen, associadas à uma proteína metabolizável melhor balanceada em aminoácidos, devido à maior participação da proteína microbiana, podem explicar a menor concentração de uréia plasmática nas dietas com milho floculado em comparação com o milho moído fino.

A ausência de diferença estatística, havendo apenas uma tendência de menores valores de $\mathrm{pH}$ ruminal nas dietas com milho floculado $(5,93$ e 5,88$)$ em relação às dietas com milho moído $(6,64$ e 6,31), pode ser explicada pelo CMS abaixo do previsto. Zinn et al. (1995) mostraram que, em animais recebendo dietas com alto teor de concentrado, além do processamento do grão, uma maior ingestão de MS provoca diminuição no pH ruminal. No presente estudo, os valores de $\mathrm{pH}$ ruminal nas dietas com milho moído fino, foram semelhantes ao 
reportado por Devant et al. (2001) $(6,27)$; Fu et al. $(2001)(6,14)$ e mais elevados que os de Zinn et al. (1995) $(6,18-5,97)$ e Shain et al. (1998) $(5,97)$.

Uma maior disponibilidade de energia para o animal também é verificada quando a fonte de amido apresenta maior degradabilidade ruminal, em função de uma maior liberação de acetato pelo sistema esplânico, assim como uma maior síntese hepática de glucose, devido à maior disponibilidade principalmente de $C_{3}$, produzido no rúmen (Huntington, 1997; Theurer et al., 1999), como observado neste estudo, nas dietas com milho floculado.

De modo geral a substituição total do farelo de soja pela uréia, não afetou nenhum dos parâmetros ruminais e sanguíneos avaliados neste estudo. Knaus et al. (2001), trabalhando com dietas semelhantes à deste estudo, também não observaram diferenças nas concentrações de uréia plasmática entre uréia e farelo de soja como suplementos protéicos para novilhos em terminação. As concentrações de $\mathrm{N}-\mathrm{NH}_{3}$ não foram afetadas pelas fontes protéicas, provavelmente devido ao alto teor de amido das dietas, que propiciou energia suficiente para a utilização eficiente da $\mathrm{NH}_{3}$ liberada pela uréia. Devant et al. (2001) trabalhando com novilhos, recebendo dietas com alto teor de concentrado, observaram valores médios mais altos de $\mathrm{N}-\mathrm{NH}_{3}$ ruminal $(8,5 \mathrm{mg} / \mathrm{dl})$ em dietas com milho moído e farelo de soja, em comparação à dietas com 
milho moído e farelo de soja + uréia $(13,8 \mathrm{mg} / \mathrm{dl})$.Vale observar, que em nosso estudo, em termos numéricos, houve um aumento não significativo $(P>0,05)$ na concentração ruminal de $\mathrm{N}-\mathrm{NH}_{3}$, quando a uréia substituiu o farelo de soja nas dietas contendo milho moído fino, fato este não observado para o milho floculado, o que permite inferir sobre uma possível melhor sincronização da degradação ruminal entre uréia e milho floculado que uréia e milho moído fino.

Fu et al. (2001) observaram valores de $\mathrm{N}-\mathrm{NH}_{3}$ ruminal de 2,53 $\mathrm{mg} / \mathrm{dl}$ a $25,68 \mathrm{mg} / \mathrm{dl}$ em dietas com níveis crescentes de PB (9\% - 20\%), respectivamente. A dieta que continha teor de PB próximo aos deste trabalho (12\%), apresentou uma concentração média de $\mathrm{N}-\mathrm{NH}_{3}$ ruminal de $8,81 \mathrm{mg} / \mathrm{dl}$.

\subsubsection{Digestibilidade ruminal}

Devido aos dados inconsistentes do marcador nas amostras duodenais das dietas com milho moído fino, não foi possível determinar a digestibilidade ruminal dos nutrientes, mas a concentração de amido observada no bolo alimentar do duodeno foi significativamente $(P<0,01)$ maior para milho moído fino $(51,4 \%$ e $50,6 \%)$ em relação às dietas com 
milho floculado $(25,2 \%$ e $30,9 \%)$. Isto sugere uma maior digestibilidade ruminal do amido no milho floculado em relação ao milho moído fino, fato este amplamente relatado na literatura (Huntington, 1997; Theurer et al., 1999).

A proposta de uma maior digestibilidade ruminal do amido do milho floculado no presente estudo, é reforçada pela menor concentração de $\mathrm{N}-\mathrm{NH}_{3}$ ruminal, o que provavelmente favoreceu a síntese microbiana. Também, a maior concentração de $\mathrm{PB}(\mathrm{P}<0,01)$ no conteúdo duodenal dos novilhos alimentados com milho floculado (22,9\% e 22,9\%), em comparação com o moído fino (16,0\% e 15,9\%), sugerem uma maior passagem de proteína para o duodeno, seja devido a uma maior síntese microbiana e ou uma maior passagem de proteína dietária.

A maior concentração $(P<0,001)$ de $F D N$ no conteúdo duodenal dos novilhos alimentados com milho floculado (28,5 e $22,8 \%)$, sugerem uma menor digestão ruminal da fibra em dietas com maior teor de amido degradável no rúmen, fato este observado na maioria dos trabalhos publicados na literatura (Huntington, 1997 e Theurer et al., 1999).

Apesar da impossibilidade da determinação dos valores de digestibilidade ruminal no presente estudo, combinando todos os dados discutidos até o momento, como: os menores teores de $\mathrm{N}-\mathrm{NH}_{3}$ e os 
maiores teores de $C_{3}$ no fluido ruminal, a tendência de menores valores de $\mathrm{pH}$, aliados à concentrações mais baixas de amido e mais elevadas de proteína e FDN no conteúdo duodenal de novilhos alimentados com milho floculado, sugerem uma maior degradabilidade ruminal do amido e uma maior síntese microbiana.

As fontes protéicas não afetaram $(P>0,05)$ as concentrações de amido e proteína no conteúdo duodenal. Estes resultados sugerem que as fontes protéicas utilizadas neste trabalho, apesar de estarem disponíveis em tempos e quantidades diferentes no rúmen, não limitaram a síntese de proteína microbiana.

Zinn \& Shen (1998) fornecendo dietas com apenas $11 \%$ de PB e com $65 \%$ de milho floculado $+8 \%$ de melaço, para novilhos em crescimento, observaram fluxos de $\mathrm{N}$ não amoniacal, $\mathrm{N}$ dietário e $\mathrm{N}$ microbiano, e digestão ruminal da matéria orgânica, superiores para a uréia em comparação com o farelo de soja. Em comparação com a farinha de peixe, a uréia também propiciou maior fluxo de proteína microbiana e maior digestão ruminal da matéria orgânica. O desempenho animal foi similar entre a uréia e o farelo de soja, porém superiores à farinha de peixe.

Knaus et al. (2001), utilizando novilhos em crescimento, alimentados com dietas contendo mais de $13 \%$ de PB e 70 a $80 \%$ de milho quebrado, observaram que a suplementação de fontes protéicas 
ricas em PNDR balanceadas em aminoácidos (mistura de farinha de carne e ossos suína, farinha de peixe, farinha de pena e farinha de sangue) não aumentaram a digestibilidade, o balanço e a eficiência de utilização do N em comparação com farelo de soja ou uréia.

É provável que em dietas com teores de proteína bruta mais elevados, ao redor de 12,5 a $14,5 \%$ como os utilizados em nosso estudo e nos confinamentos comerciais (Galyean, 1996), o farelo de soja seja capaz de suprir adequadamente, as necessidades ruminais de PDR. Entretanto, em função do menor custo da uréia, esta deve ser sempre a fonte suplementar de proteína, preferencial em dietas ricas em amido degradável no rúmen para novilhos em terminação.

Animais jovens em crescimento, com até $300 \mathrm{~kg}$ de PV, podem responder à fontes de proteína verdadeira como o farelo de soja, em comparação com suplementação exclusiva de uréia, mesmo em dietas altas em concentrado. Dados preliminares de um estudo em andamento, no Departamento de Produção Animal da ESALQ/USP em Piracicaba-SP (Pires, comunicação pessoal), mostraram que nos primeiros 33 dias de confinamento, tourinhos Nelore e Canchim, com 10 a 14 meses de idade e pesando ao redor de 230 a $330 \mathrm{~kg}$, tiveram ganho de peso (1,4 para Canchim e 1,16 para Nelore) similares com dietas contendo $14 \%$ de PB e $60 \%$ de concentrado e $40 \%$ de silagem de capim + polpa cítrica, quando farelo de soja ou uma combinação de 
farelo de soja + uréia foram comparados. Entretanto, a suplementação exclusiva com uréia, resultou em menor desempenho dos animais.

\subsubsection{Digestibilidade no trato total}

O consumo de matéria seca não foi afetado pelos tratamentos $(P>0,05)$. Os baixos valores observados talvez se devam à um certo grau de estresse pós cirúrgico dos animais, os quais haviam sido criados a pasto até então. Também vale frisar, que houve certa dificuldade dos animais se adaptarem aos bebedouros automáticos utilizados.

Apesar da ausência de significância estatística, um menor valor numérico para CMS foi observado para as dietas com milho moído fino. Em experimento conduzido com vacas leiteiras, Yu et al. (199..) também observaram menor consumo de MS nas dietas com milho moído fino em comparação com o milho floculado, sendo o volumoso utilizado o feno de alfafa. Entretanto, ensaios também conduzidos com vacas leiteiras no Brasil, só que utilizando volumoso úmido como a silagem de milho, não mostraram menor consumo das dietas contendo milho moído fino em relação ao floculado ou processado com pipoca (Menezes Jr, 1999; Santos et al., 2001). 
A digestibilidade da MS no trato digestivo total, não foi afetada pelos tratamentos $(P>0,05)$. Zinn \& Shen (1998) também não observaram efeito da fonte protéica (uréia, farelo de soja, farinha de peixe) na digestibilidade da matéria orgânica no trato digestivo total. Os valores observados neste trabalho $(68,4$ a $74,7 \%)$ foram próximos aos valores apresentados por Lapierre et al. (2000) (73,8\%); Knaus et al. (2001) (73,3\%) e Castillo et al. (2001) (76,1\%). Entretanto, foram inferiores aos de Fu et al. (2001) (84,9\%) em dietas com milho moído e níveis crescentes de proteína degradável no rúmen, trabalhando com novilhos na tentativa de maximizar a digestibilidade de nutrientes no rúmen e a eficiência microbiana, assim como em relação aos dados de Ferrell et al. (2001) (83,3\%), que trabalharam com ovelhas recebendo dietas a base de milho moído e diferentes fontes protéicas.

A ausência de diferença no CMS das dietas, explica o fato dos consumos de PB e FDN não terem sido afetados pelos tratamentos. Entretanto, a tendência de maior CMS nas dietas com milho floculado, resultou em tendência $(P<0,14)$ de maior consumo de $P B$, o que pode em parte explicar a menor $(P<0,07)$ digestibilidade deste nutriente $P B$ nessas dietas. Outro fator que merece consideração é o provável maior fluxo de proteína bruta para o duodeno, discutido anteriormente.

A ausência de efeito na digestibilidade da proteína bruta no trato digestivo total também foi observada por Zinn \& Shen (1998), 
comparando uréia, farelo de soja e farinha de peixe para novilhos recebendo dietas contendo milho floculado, semelhantes às usadas no presente estudo.

O consumo $(P<0,06)$ e a digestibilidade $(P<0,05)$ do amido no trato total, foram afetados pelas fontes de amido. A floculação aumentou o teor de amido da dieta, o que pode ser um artefato, já discutido anteriormente, justificando o maior consumo deste nutriente. A maior digestibilidade do amido no trato total quando o milho foi floculado, está de acordo com a literatura revisada por Huntington (1997) e por Theurer et al. (1999), assim como os valores observados para o milho floculado, ao redor de 98 a 99\%. Já os valores observados para o milho moído fino, estão abaixo do esperado, próximos aos valores relatados para milho moído grosso ou laminado seco.

A maior digestibilidade do amido pode resultar em maior disponibilidade de energia para o ruminante, assim como uma maior disponibilidade de aminoácidos, uma vez que materiais com alta digestibilidade total, normalmente têm alta degradabilidade ruminal, favorecendo a síntese microbiana (NRC, 2001).

A menor digestibilidade do FDN $(P<0,01)$ nas dietas contendo milho floculado, $(9,52 \%$ 14,63\%) em comparação com o moído fino $(45,81 \%$ e $37,85 \%)$ tem sido observado em diversos trabalhos, especialmente os com bovinos confinados recebendo dietas com altos 
teores de concentrado. Em dietas para vacas leiteiras, contendo entre 40 a $60 \%$ de forragem, a digestão da FDN no intestino grosso, tem sido capaz de compensar os efeitos negativos ocorridos no rúmen, devido ao aumento da degradabilidade do amido de milho ou sorgo floculado .

Os valores obtidos para digestibilidade do FDN no trato total, são normais para dietas contendo milho moído fino, porém extremamente baixos nas dietas com milho floculado, o que pode indicar algum problema de amostragem ou de análise laboratorial.

A menor digestibilidade do FDN com milho floculado pode Ter compensado a maior digestibilidade do amido impedindo que a digestibilidade da MS fosse aumentada com a floculação do milho como relatada em outros trabalhos por Theurer et al. (1999).

5.1.4 Fluxo de proteína microbiana e aminoácidos totais

O fluxo de proteína microbiana e a quantidade de aminoácidos totais não foram possíveis de serem determinados, pois o óxido de cromo, utilizado para estimar a digestibilidade ruminal aparente da matéria seca, não apresentou valores consistentes, sendo em alguns casos até negativo. Isto talvez tenha ocorrido devido ao baixo consumo 
diário de matéria seca pelos animais, além de uma grande diferença neste consumo entre animais, o que interferiu na concentração do marcador fornecido. Uma vez que a metodologia empregava o fornecimento de uma quantidade fixa e predeterminada. 


\section{CONCLUSÕES}

O aumento da degradação ruminal do amido, através da floculação do milho, melhorou a nutrição energética e protéica de novilhos de corte em terminação, devido à em melhor utilização da $\mathrm{N}-\mathrm{NH}_{3}$ ruminal, aumento na concentração molar de $C_{3}$ no fluido ruminal, redução da concentração de uréia plasmática, tendência de melhor consumo de MS, e aumento na digestão de amido no trato total. Entretanto, a digestibilidade da MS da dieta não foi aumentada, devido à redução na digestibilidade do FDN.

Em dietas formuladas para alto desempenho de novilhos em terminação, contendo 50 a $70 \%$ de amido e 12 a $13 \%$ de PB, a uréia pode ser usada como fonte suplementar exclusiva de $\mathrm{N}$. 


\section{REFERÊNCIAS BIBLIOGRÁFICAS}

ALDRICH, J. M.; MULLER, L. D.; VARGA, G. A.; GRIEL, L. C. Nonstructural carbohydrate and protein effects on rumen fermentation, nutrient flow, and performance of dairy cows. Journal of Dairy Science, v. 76, p. 1091 - 1100, 1993.

ALIO, A.; THEURER, C. B.; LOZANO,O.; HUBER,J.T.; SWINGLE, R. S.; DELGADO-ElORDUY, A.; CUNEO, P.; DEYOUNG, D.; WEBB, Jr. K. E. Splanchnic nitrogen metabolism by growing beef steers fed diets containing sorghum grain flaked at different densities. Journal of Animal Science, v. 78, p. 1355 - 1365, 2000 .

ASSOCIATION OF OFFICIAL ANALYTICAL CHEMISTS. Official methods of analysis. 15.ed. Washington, 1990. 473p.

BARAJAS, R.; ZINN, A. The feeding value of dry-rolled and steam-flaked corn in finishing diets for feedlot cattle: influence of protein supplementation. Journal of Animal Science, v. 76, p. 1744 - 1752, 1998.

BEAUACHEMIN, K. A.; YANG, W. Z.; RODE, L. M. Effects of barley grain processing on the site and extent of digestion of beef feedlot finishing diets. Journal of Animal Science, v. 79, p. 1925 - 1934, 2001.

BEAUACHEMIN, K. A.; McALLISTER, T.A.; DONG, Y.; FARR, B.I.; CHENG, K.J. Effects of mastication on digestion of whole cereal grains by cattle. Journal of Animal Science, v. 72, p. 236 - 246, 1994. 
BERGMAN, E.N. Energy contributions of volatile fatty acids from the gastrointestinal tract in various species. Physiological Reviews, v. 70, n. 2, p. 567 - 574, 1990.

BROWN, M. S.; KREHBIEL, C. R.; DUFF, G. C.; GALYEAN, M. L.; HALLFORD, D. M.; WALKER, D. A. Effect of degree of corn processing on urinary nitrogen composition, serum metabolite and insulin profiles, and performance by finishing steers. Journal of Animal Science, v. 78, p. 2464 - 2474, 2000.

CAMERON M.R.; KLUSMEYER, T.H.; LYNCH, G.L.; CLARK, J.H.; NELSON, D.R. Effects of urea and starch on rumen fermentation, nutrient passage to the duodenum, and performance of cows. Journal of Dairy Science, v. 74, p.1321 - 1331. 1991.

CASS, J.L.; RICHARDSON, C.R.; SMITH, K J. Evaluation of slow ammonia release from urea / calcium compounds. Journal of Animal Science, v. 72, p. 234 - 244, 1994.

CASTILlO, A. R.; KEBREAB, E.; BEEVER, D. E.; BARBI, J. H.; SUTTON, J.D.;KIRBY, H. C.; FRANCE, J. The effect of energy supplementation on nitrogen utilization in lactating dairy cows fed grass silage diets. Journal of Animal Science, v. 79, p. 240 - 246, 2001a.

CASTIllo, A. R.; KEBREAB, E.; BEEVER, D. E.; BARBI, J. H.; SUTTON, J.D.;KIRBY, H. C.; FRANCE, J. The effect of protein supplementation on nitrogen utilization in lactating dairy cows fed grass silage diets. Journal of Animal Science, v. 79 , p. $247-253,2001 b$.

CHANEY, A.L.; MARBACH, E P. Modified reagents for determination of urea and ammonia. Clinical Chemistry, v. 8, p. 130 - 137, 1962.

CLARK, J. H.; KLUSMEYER, T. H.; CAMERON, M. R. Symposium: nitrogen metabolism and amino acid nutrition in dairy cattle. Journal of Dairy Science, v. 75, p. $2304-2323,1992$. 
COOMER, J.C.; AMOS, H.E.; FROETSCHEL, M.; RAGLAND, K.K.; WILLIAMS, C.C. Effects of supplemental protein source on ruminal fermentation, protein degradation, and amino acid absorption in steers and on growth and feed efficiency in steers and heifers. Journal of Animal Science, v. 71, p. 3078 - 3089, 1993.

DELFINO, F.J. Identification and characterization of cereal grain tissues resistant to rumen microbial digestion using in situ, in vitro and scanning electron microscope techniques. Tucson, 1986. 108p. Dissertation (Ph.D.) - University of Arizona.

DePETERS, E.J.; CANT, J.P. Nutritional factors influencing the nitrogen composition of bovine milk: a review. Journal of Dairy Science. v. 75, p. 2043 - 2050. 1992.

DEVANT, M.; FERRET, A.; CALSAMIGLIA, S.; CASALS, R.; GASA, J. Effect of nitrogen source in high-concentrate, low-protein beef cattle diets on microbial fermentation studied in vivo and in vitro. Journal of Animal Science, v. 79, p. 1944 - 1955, 2001.

DEVANT, M.; FERRET, A.; GASA, J.; CALSAMIGLIA, S.; CASALS, R. Effects of protein concentration and degradability on performance, ruminal fermentation, and nitrogen metabolism in rapidly growing heifers fed high-concentrate diets from 100 to $230 \mathrm{Kg}$ body weight. Journal of Animal Science, v. 78, p. 1667 - 1676, 2000.

FAHEY, G.C.; BERGER, L.L. Carbohydrate nutrition of ruminants. In: CHURCH, D.C. The ruminant animal: digestive physiology and nutrition Englewood Cliffs: Simon \& Schuster, 1988.p. $128-154$.

FERRELL, C. L.; FREETLY, H. C.; GOESTCH, A. L.; KREIKEMEIER, K. K. The effect of dietary nitrogen and protein on feed intake, nutrient digestibility, and nitrogen flux across the portal-drained viscera and liver of sheep consuming highconcentrate diets ad libitum. Journal of Animal Science, v. 79, p. 1322 - 1333, 2001. 
FU, C. J.; FELTON, E. E. D.; LEHMKUHLER., J. W.; KERLEY, M. S. Ruminal peptide concentration required to optimize microbial growth and efficiency. Journal of Animal Science, v. 79, p. 1305 - 1314, 2001.

GAEBE, R. J., SANSON, D. W., RUSH, I. G., RILEY, M.L.,HIXON, D. L.; PAISLEY, S. I. Effects of extruded corn or grain sorghum on intake digestibility, weight gain, and carcass of finishing steers. Journal of Animal Science, v. 76, p. 2001 - 2011, 1998.

GALYEAN, M. L. Protein levels in beef cattle finishing diets: industry application, university research, and systems results. Journal of Animal Science, v. 74, p. 2860 - 2870, 1996.

GUILBOT, A.; MERCIER, C. Starch in the polysaccharides. Orlando: Academic Press, 1985. 121 p.

HELMER, L.G. Feed processing. V. Effect of expansion-processed mixture of grain and urea (Starea) on nitrogen utilization in vitro. Journal of Dairy Science, v. 53, p. $330-340,1970$.

HERRERA-SALDANA, R.; HUBER, J.T. Influence of varying protein and starch degradability on performance of lactating cows. Journal of Dairy Science, v.72, p.1477 - 1486, 1989.

HERRERA-SALDANA, R; GOMES-ALARCON, R.; TORABI, M.; HUBER, J.T.. Influence of synchronizing protein and starch degradation in the rumen on nutrient utilization and microbial protein synthesis. Journal of Dairy Science, v.73, p.142 $151,1990$.

HOOVER, C.W.; STOKES, S.R. Balacing carbohydrates and proteins for optimum rumen microbial yield. Journal of Dairy Science. v. 74, p. 3630 - 3640. 1991. 
HRISTOV, A. N.; IVAN, M.; RODE, L. M.; McAlliSTER, T. A. fermentation characteristics and ruminal ciliate protozoa populations in cattle fed medium or highconcentration barley-based diets. Journal of Animal Science, v. 79, p. 515 - 525, 2001.

HUBER, J. T.; HERRERA-SALDANA, R. Synchrony of protein and energy supply to enhance fermentation. In: ASPLUND, J. M. Principles of protein nutrition of ruminants. Boca Raton: C.R.C. Press, 1994. p. 31 - 52.

HUCK,G. L., KREIKEMEIER, K. K., KUHL, G. L., ECK, T. P.; BOLSEN, K. K. Effects of feeding combinations of steam-flaked grain sorghum and steam- flaked, high-moisture, or dry-rolled corn on growth performance and carcass characteristics in feedlot cattle. Journal of Animal Science, v. 76, p. 2984 - 2995, 1998.

HUNTINGTON, G.B. Ruminant starch utilization progress has been extensive. Feedstuffs, p. 35 , 06 June 1994.

HUNTINGTON, G. B. Starch utilization by ruminants: from basics to the bunk. Journal of Animal Science, v.75, p. 852 - 862, 1997.

HUNTINGTON, G.; POORE, M.; HOPKINS, B.; SPEARS, J. Effect of ruminal protein degradability on growth and $\mathrm{N}$ metabolism in growing beef steers. Journal of Animal Science. v. 79, p. 533 - 543, 2001.

JOY, M.T; DePETERS, J.; FADEL, J.G.; ZINN, R.A. Effects of corn processing on the site and extent of digestion in lactating cows. Journal of Dairy Science, v.80, p.2087 - 2094, 1997.

KNAUS, W. F.; BEERMANN, D. H.; GUYROY, P. J.; BOEHM, M. L. FOX, D. G. Optimization of rate and efficiency of dietary nitrogen utilization through the use of animal by-products and (or) urea and their effects on nutrient digestion in Holstein steers. Journal of Animal Science, v. 79, p. 753 - 761, 2001. 
KOTARSKI, K.K.; WANISHA, R.D.; THURN, K.K. Starch hydrolysis by the ruminal microflora. Journal of Nutrition, v. 122, p. 178 - 184. 1992.

KREHBIEL, C. R.; KREIKEMEIER, K. K.; FERRELL, C. L. Influence of Bos indicus crossbreeding and cattle age on apparent utilization of a high-grain diet. Journal of Animal Science, v. 78, p. 1641 - 1650, 2000.

LOZANO, O.; THEURER, C. B.; ALIO, A.; HUBER, J. T.; DELGADO-ELORDUY, A.; CUNEO, P.; DeYOUNG, D.; SADIK, M.; SWINGLE, R. S. Net absorption and hepatic metabolism of glucose, 1-lactate, and volatile fatty acids by steers fed diets containing sorghum grain processed as dry-rolled or steam-flaked at different densities. Journal of Animal Science, v. 78, p. 1364 - 1375, 2000.

LYCOS, T.; VARGA, G.A.; CASPER, D. Varying degradation rates of total nonstructural carbohydrates: Effects on ruminal fermentation, blood metabolites and milk production and composition in high producing Holstein cows. Journal of Dairy Science, v. 80, p. 3341 - 3352, 1997.

McALLISTER, T.A.; RODE, L.M.; MAJOR, D.J. CHUNG, K.J. Microbial attachment and feed digestion in the rumen. Journal of Animal Science, v. 72, p. 3004 - 3012, 1994.

McALliSTER, T.A.; RODE, L.M.; MAJOR, D.J.; CHUNG, K.J.; BUCHANANSMITH, J.G. Effect of ruminal microbial colonization on cereal grain digestion. Canadian Journal of Animal Science, v.70, p.571 - 580, 1990.

McCARTHY, R. D.; KLUSMEYER, J. L.; VICINI, J. L.; CLARK, J. H.; NELSON, D. R. Effects of source of protein and carbohydrate on ruminal fermentation and passage of nutrients to the small intestine of lactating cows. Journal of Dairy Science, v. 72, p. $2002-2016,1989$.

MEHREZ, A. Z.; ORSKOV, E. R.; McDONALD, I. Rates of rumen fermentation in relation to ammonia concentration. British Journal of Nutrition, v. 38, p. $433-$ $443,1977$. 
MENEZES Jr., M. P. Efeito do processamento do grão de milho e sua substituição parcial por polpa de citros peletizada sobre o desempenho, digestibilidade de nutrientes e parâmetros sanguíneos de vacas de leite. Piracicaba, 1999, 97p. Dissertação (Mestrado) - Escola Superior de Agricultura "Luíz de Queiroz", Universidade do Estado de São Paulo.

MILTON, C.T.; BRANDT Jr., R.T.; TITGEMEYER, E.C. Effects of dietary nitrogen source and concentration in high-grain diets on finishing steer performance and nutrient digestion. Journal of Animal Science, v. 75, p. 2813 - 2824, 1997a.

MILTON, C.T.; BRANDT Jr., R.T.; TITGEMEYER, E.C. Urea in dry-rolled corn diets: finishing steer performance, nutrient digestion, and microbial protein production. Journal of Animal Science, v. 75, p. 1415 - 1424, 1997 b.

MILTON, C.T.; BRANDT Jr., R.T.; TITGEMEYER, E.C.; KUH, G.L. Effect of degradable and escape protein and roughage type on performance and carcass characteristics of finishing yearling steers. Journal of Animal Science, v. 75, p. $2834-2844,1997$ c.

MOORE, J.A.; POORE, M.H.; ECK, T.P.; SWINGLE, R.S.; HUBER, J.T.; ARANA M.J. Sorghum grain processing and buffer additions for early lactation dairy cows. Journal of Dairy Science, v. 75, p. 3465 - 3477, 1992.

MURPHY, T. A.; FLUHARTY, F. L.; LOERCH, S. C. The influence of intake level and corn processing on digestibility and ruminal metabolism in steers fed all-concentrate diets. Journal of Animal Science, v. 72, p. 1608 - 1619, 1994.

NATIONAL RESEARCH COUNCIL. Ruminant nitrogen usage. Washington, National Academy of Science, 1985. 138p.

NATIONAL RESEARCH COUNCIL. Nutrient requirements of beef cattle. 7. ed. Washington: National Academic Press, 1996. 242p. 
NOCEK, J. E.; RUSSELL, J.B. Protein and energy as an integrated system: Relationship of ruminal protein and carbohydrate availability to microbial synthesis and milk production. Journal of Dairy Science, v.71, p.2070 -2082, 1988.

NOCEK, J. E.; TAMMINGA, S. Site of digestion of starch in the gastrointestinal tract of dairy cows and its effect on milk and composition. Journal of Dairy Science, v.74, p.3598 - 3607, 1991.

NORLAN, J. V. Quantitative models of nitrogen metabolism in sheep. In: MacDONALD, I. W.; WARNER, A. C. I. (Ed.) Digestion and metabolism in the ruminant. Armidale: University New England, 1975. p. 398 - 416.

OLIVEIRA, J.S.; HUBER, J.T.; BEN-GHEDALIA D.; SWINGLE R.S.; THEURER C.B.; PESSARAKLI, M. Influence of sorghum grain processing on performance of lactating dairy cows. Journal of Dairy Science, v.76, p.575 - 584, 1993.

OLSON, K. C.; COCHRAN, R. C.; JONES, T. J.; VANZANT, E. S.; TITGEMEYER, E. C.; JOHNSON, D.E. Effects of ruminal administration of supplemental degradable intake protein and starch on utilization of low-quality warm-season grass hay by beef steers. Journal of Animal Science, v. 77, p. 1016 - 1026, 1999.

OWENS, F.N.; GOETSCH, A.L. Digest passage and microbial protein synthesis. In: MilligAN, L.P.; GROVUM, W.L.; DOBSON, A. (Ed.) Control on digestion and metabolism in ruminants. Englewood Cliffs: Prentice Hall, 1986. cap. 8, p. 196 223.

OWENS, F.N.; ZINN, R.A.; KIM, Y.K. Limits to starch digestion in the ruminant small intestine. Journal of Animal Science, v. 63, p.1634 - 1643, 1986.

OWENS, F. N.; SECRIST, D. S.; HILL, W. J.; GILL, D. R. The effect of grain processing on performance of feedlot cattle: a review. Journal of Animal Science, v. 75, p. $868-877,1997$. 
PARRÉ, C. Utilização da uréia e da zeolita na alimentação de ovinos. Jaboticabal, 1995. 96p. Tese (Doutorado) - Faculdade de Ciências Agrárias e Veterinárias, Universidade Estadual Paulista “Júlio de Mesquita Filho".

PERRY, T. W.; CECAVA, M.J. Beef cattle feeding and nutrition. 2. ed. San Diego: Academic Press, 1995. 58p.

PLASCENCIA, A.; ZINN, R. A. Influence of flake density on the feeding value of steam-processed corn in diets for lactating cows. Journal of Animal science, v. 74, p. $310-316,1996$.

REDDY, P.K.; RAO,S.B.; PRASAD, D.A. Development and evaluation of extruded deoild salseed meal urea products (salurea 50 and salurea 70 in vitro and in vivo methods). Indian Journal of Animal Science, v.5, p.604 - 612, 1981.

REYNOLDS, C.K.; HUNTINGTON, G.B. Net portal absorption of volatile fatty acids and L (+) lactate by Holstein cows. Journal of Dairy Science, v.71, p. 124 - 133. 1988.

ROBINSON, P.H. Dynamic aspects of feeding management for dairy cows. Journal of Dairy Science, v. 72, p. 1197 - 1205. 1989.

ROONEY, L. W.; PFLUGFELDER, R.L. Factors affecting starch digestibility with special emphasis on sorghum and corn. Journal of Animal Science, v. 63, p. 1607 $1617,1986$.

RUSSEL, J.B.; HESPELL, R.B. Microbial rumen fermentation. Journal of Dairy Science. v. 64, p. 1153 - 1161. 1981.

RUSSEL, J.B.; SNIFFEN, C.J.; VAN SOEST, P.J. Effect of carbohydrate limitation on degradation and utilization of casein by mixed rumen bacteria. Journal of Dairy Science, v. 66, p. 763 - 770, 1983. 
RUSSELL, J. B.; O CONNOR, J. D.; FOX, D. G.; VAN SOEST, P. J.; SNIFFEN, C. J. A net carbohydrate and protein system for evaluating cattle diets. Journal of Animal Science, v. 70, p. $3551-3561,1992$.

SANTOS, F.A.P.; SANTOS, J.E.P.; HUBER, J.T.; THEURER, C.B. Response of lactating cows to various densities of sorghum grain. Journal of Dairy Science, v. 75, n. 8, p. 1681-1685, 1997.

SANTOS, F.A.P.; SANTOS, J.E.P.; THEURER, C.B.; HUBER, J.T. Effects of rumenundegradable protein on dairy cow performance: a 12-year literature review. Journal of Dairy Science, v. 81, p. 3182 - 3213, 1998.

SAS INSTITUTE. SAS users guide: statistics; version 5. Cary, 1991. 213p.

SATTER, L. D.; SLYTER, L.L. Effect of ammonia concentration on rumen microbial protein production in vitro. British Journal of Nutrition, v. 32, p. 199-205, 1974.

SEIXAS, J.R.C. Desempenho de bovinos confinados e digestibilidade aparente com ovinos recebendo amiréia, uréia ou farelo de algodão. Jaboticabal, 1996, 73p. Dissertação (Mestrado) - Faculdade de Ciências Agrárias e Veterinárias, Universidade Estadual Paulista "Júlio de Mesquita Filho".

SHAIN, D. H.; STOCK, R. A.; KLOPFENSTEIN, T. J.; HEROLD, D. W. Effects of degradable intake protein level on finishing cattle performance and ruminal metabolism. Journal of Animal Science, v. 76, p. 242 - 254, 1998.

SIMAS, J. M. Processamento de grãos para rações de vacas leiteiras. In: $9^{\circ}$ SIMPÓSIO SOBRE PRODUÇÃO ANIMAL, Piracicaba, 1997. Anais. Piracicaba: FEALQ, 1997. p. $7-32$.

SLYTER, L. L.; SATER, L. D.; DINIUS, D. A Effect of ruminal ammonia concentration on nitrogen utilization by steers. Journal of Animal Science, v. 48, p. $906-1012,1979$. 
SNIFFEN, C.J.; ROBINSON, P.H. Microbial growth and flow as influenced by dietary manipulations. Journal of Dairy Science, v. 70, p. 425 - 434, 1987.

SPICER, L. A.; THEURER, C. B.; SOWE, J.; NOON, T. H. ruminal and post-ruminal utilization of carbohydrate and protein system for evaluating cattle diets. Journal of Animal Science, v. 62, p. 521 - 531, 1986.

SWINGLE, R. S.; ECK, T. P.; THEURER, C. B.; DE LA LLATA, M.; POORE, M. H.; MOORE, J. A. Flake density of steam-processed sorghum grain alters performance and sites of digestibility by growing-finishing steers. Journal of Animal Science, v. 77, p. 1055 - 1061, 1999.

TEIXEIRA, J.C. Nutrição de ruminantes. Lavras: Edições FAEPE, 1997. 96p.

THEURER, C.B. Grain processing effects on starch utilization by ruminants. Journal of Animal Science, v. 63, p. 1649 - 1657. 1986.

THEURER, C.B. Steam-flaked grain for high producing dairy cows. In: SOUTHWEST NUTRITION MANAGE CONFERENCE, Tucson, 1992. Steam-flaked grain for high producing dairy cows. Tucson: University of Arizona, Dept. of Animal Science, 1992. p. $64-68$.

THEURER, C.B.; HUBER, J.T.; SANTOS, F.A.P. Feeding and managing for maximal milk protein. In: PROCEEDINGS OF SOUTHWEST NUTRITION AND MANAGEMENT CONFERENCE, Tucson, 1995. Feeding and managing for maximal milk protein. Tucson: University of Arizona, Dept. of Animal Science, 1995. p. $59-64$.

THEURER, C. B.; HUBER, J.T.; DELGADO-ELORDUY, A.; WANDERLEY, R. Summary of steam-flaking corn or sorghum grain for lactating dairy cows. Journal of Dairy Science, v. 82, p. 1950 - 1959, 1999.

VAN SOEST, P.J. Nutrition ecology of the ruminants. Ithaca: Cornell University Press, 1994. 476 p. 
VAN SOEST, P.J.; ROBERTSON, J.B.; LEWIS, B.A. Methods for dietary fiber, neutral detergent fiber, and nonstarch polysaccharides in relation to animal nutrition. Journal of Dairy Science, v. 74, p. 3583 - 3591, 1991.

YOKOYAMA, M.T.; JOHNSON, K.A. Microbiology of the rumen and intestine. In: CHURCH, D.C. The ruminant animal: digestive physiology and nutrition Englewood Cliffs: Simon \& Schuster, 1988. p. 98 - 125.

YU, P.; HUBER, J. T.; SANTOS, F. A. P.; SIMAS, J.M.; HUBER, C. B. Effects of ground, steam-flaked, and steam-rolled corn grains on performance of lactating cows. Journal of Dairy Science, v. 81, p. 777 - 783, 1998.

ZINN, R. A.; BARAJAS, R. Comparative ruminal and total tract digestion of a finishing diet containing fresh vs air-dry steam-flaked corn. Journal of Animal Science, v. 75, p. $1704-1715,1997$.

ZINN, R. A.; SHEN, Y. An evaluation of ruminal degradable intake protein and metabolizable amino acid requirements of feedlot calves. Journal of Animal Science, v. 76, p. 1280 - 1289, 1998.

ZINN, R.A.; OWENS, F.N. A rapid procedure for purine measurement and its use for estimating net ruminal protein synthesis. Canadian Journal of Animal Science, v. 66, p. $157-166,1986$.

ZINN, R. A.; OWENS, F. N. Ruminal escape protein for lightweight feedlot calves. Journal of Animal Science, v. 71, p. 1677 - 1687, 1993. 